\title{
CONSTITUCIÓN Y DERECHOS HISTÓRICOS: LEGITIMIDAD DEMOCRÁTICA FRENTE A LEGITIMIDAD HISTÓRICA ${ }^{1}$
}

\author{
JAVIER TAJADURA TEJADA \\ Profesor Titular de Derecho Constitucional \\ Universidad del País Vasco
}

\begin{abstract}
SUMARIO
I. Introducción.

II. Las raíces profundas del historicismo en el constitucionalismo español.

III. La problemática recepción constitucional de los derechos históricos: las advertencias del profesor García Pelayo.

IV. El desarrollo de los derechos históricos en los Estatutos de Autonomía.

V. El fortalecimiento del historicismo en la revisión del Estado Autonómico

VI. Las denominadas "normas constitucionales inconstitucionales": la inconstitucionalidad de la Disposición Adicional Primera de la Constitución

VII. La necesaria reforma constitucional de carácter "depurativo"

VIII. Conclusiones.
\end{abstract}

1 La tesis central de este estudio fue publicada de forma sintética en Claves de Razón Práctica, núm. 177, noviembre de 2007, (págs. 48-53) con el título de "Los 'privilegios' forales". Agradezco al profesor Oscar Alzaga su invitación para desarrollarla en profundidad en esta Revista. Por otro lado, este trabajo se ha elaborado en el marco del Grupo Consolidado de Investigación en Historia intelectual de la política (IT-384-07), dirigido por Javier Fernández Sebastián y financiado por el Departamento de Educación, Universidades e Investigación del Gobierno Vasco. 


\section{INTRODUCCIÓN.}

En un sugerente ensayo sobre la problemática de nuestra organización territorial, el profesor Gil Calvo ${ }^{2}$, pone de manifiesto cómo la "deriva autonómica" que padece nuestro Estado conduce, inexorablemente, a la confederalización de España, esto es, a su disolución como Estado Constitucional unitario. Y, con no menor sagacidad, advierte cómo es la propia Constitución de 1978 la que contiene en su seno el germen de su destrucción. Y ello por la razón evidente de que, contra toda lógica jurídica y política democrática, el Constituyente de 1977-78 — bajo la presión del terrorismo etarra- introdujo en el Texto Constitucional un precepto (la disposición adicional primera que ampara los derechos históricos de determinados territorios) que sólo tiene sentido desde una óptica confederal: "La más insidiosa simiente confederal, aunque legitimada y garantizada por la Constitución, es la sobrevivencia del privilegio foral, que Franco había otorgado a la 'nueva Covadonga insurgente' de las provincias de Alava y Navarra para premiar su decisivo apoyo al Alzamiento pero que la democracia consagró ampliándolo a las provincias de Guipúzcoa y Vizcaya, con la fallida esperanza de apaciguar al independentismo y al terrorismo vascos. Este arcaico privilegio foral, incompatible con una Hacienda Pública de tipo federal, se ha articulado en forma de unos excepcionales Conciertos Económicos, privativos de las provincias vasconavarras, que les garantizan en la práctica una financiación independiente derivada de su efectiva soberanía fiscal, y que, desde luego contradicen la letra y el espíritu de la igualdad de los españoles ante la ley en materia fiscal" 3 .

En estas páginas quiero poner de manifiesto, por una parte, que los peligros y los riesgos derivados de incluir en la Constitución los privilegios forales a través de la categoría de los 'derechos históricos', ya fueron advertidos - con escaso éxito- durante el proceso constituyente; por otra, que la experiencia ha demostrado que esos peligros son reales. No sólo porque al amparo de los derechos históricos se defiende hoy el derecho de secesión, sino, sobre todo, porque las singularidades derivadas de los mismos han disparado una espiral reivindicativa cuyo final no se vislumbra. El proceso de reformas estatutarias llevado a cabo durante la VIII Legislatura así lo confirma. En este contexto, sostengo y desarrollo la tesis de que la Disposición Adicional primera (en adelante DAP) de la Constitución es un caso paradigmático de lo que la doctrina constitucional alemana (Bachof) denomina "norma constitucional inconstitucional". El Constituyente no puede incluir cualquier cosa en el Texto Constitucional. En concreto, como expondré después, no puede in-

2 Gil Calvo, E.: "La deriva autonómica” en Claves de Razón práctica, n. 172, mayo 2007, págs. 26-36.

3 GIL Calvo, E.: "La deriva autonómica»...ob.cit. pág. 27. Sobre la naturaleza confederal del Concierto, resulta imprescindible el magnífico estudio de RuIz SorOA, J.M.: "El Concierto Económico Vasco como paradigma político" en Claves de Razón Práctica, núm. 168, 2006, págs. 22-29. 
troducir excepciones al principio de legitimidad. Si lo hace, esos preceptos por contradecir el orden material de valores propio de la legitimidad democrática son inconstitucionales.

En definitiva, el objeto de este estudio no es reiterar el significado y alcance que la doctrina y el Tribunal Constitucional atribuyen a los derechos históricos, sino poner de manifiesto la gravedad de un problema. Y con esas premisas, formular una hipótesis teórica diferente de las existentes. Hipótesis que en el caso (improbable) de que fuera asumida por el Tribunal Constitucional pondría fin a la patológica perturbación que una categoría jurídica antidemocrática (derechos históricos) provoca en una Constitución normativa. En todo caso, y precisamente porque soy consciente de la dificultad que entraña que nuestro supremo custodio de la Constitución (habida cuenta la crisis de credibilidad que sufre desde 2007) asuma esa tesis, defiendo la necesidad de que sea el Poder de Reforma quien ponga fin a la peligrosa vía hacia la confederalización de España recientemente denunciada, entre otros, por Gil Calvo.

Tanto el principio democrático como el principio federal, en la medida en que se fundamentan en el valor igualdad, exigen enterrar definitivamente una categoría, los derechos históricos, que pugna con aquellos. La reforma constitucional depurativa del historicismo es la principal asignatura pendiente para la consolidación del sistema constitucional español, treinta años después de su establecimiento. Una asignatura pendiente, como vamos a ver, desde que hace doscientos años surgiera en España el régimen constitucional.

\section{LAS RAÍCES PROFUNDAS DEL HISTORICISMO EN EL CONSTITUCIONALISMO ESPAÑOL.}

Este año conmemoramos el trigésimo aniversario de nuestro Texto Constitucional. Igualmente, se cumplen dos siglos del levantamiento del 2 de Mayo que dio lugar a la denominada Guerra de la Independencia frente al invasor francés. Invasor que había elaborado para España su primer y controvertido texto constitucional, el conocido como Estatuto de Bayona de 1808. Aunque pueda sorprender, señalo ambas efemérides para poner de manifiesto la relación entre ellas. Una relación más profunda e intensa de lo que se suele advertir. Y es que, de una u otra suerte, algunos de los defectos del Texto Constitucional de 1978 encuentran su explicación en los orígenes mismos del Constitucionalismo patrio.

Nuestra primera Constitución (obviando la de Bayona), la de Cádiz, se sustentó sobre dos principios indiscutibles. El primero, la unidad de la nación, titular de la soberanía, y organizada en un Estado cuya estructura territorial habría de ser uniforme. El segundo, la igualdad de todos, sin privilegios personales o territoriales, ante las leyes del Estado elaboradas por un único legislador. En la medida en que, fueros, privilegios y derechos históricos son categorías propias del Antiguo Régimen, claramente incompatibles con los 
mencionados principios fundamentales de la Constitución gaditana, se podría considerar, como lo hace el profesor Tomás y Valiente, que nuestra primera Constitución impuso la desaparición del régimen foral. Y ello sin necesidad de una derogación expresa en tal sentido ${ }^{4}$. Pero no fue así. Antes bien, lo cierto es que algunos de los fundamentos ideológicos de la Constitución de Cádiz favorecieron la continuidad del Antiguo Régimen, cuya compatibilidad en algunos extremos se declaró expresamente en el nuevo Texto Constitucional ${ }^{5}$.

La Guerra de la Independencia fue el acontecimiento decisivo para la forja del sentimiento nacional español y para el nacimiento mismo de la idea de nación española. La ocupación de España por el ejército francés era la más clara demostración de la situación de decadencia que sufríamos. En ese contexto, los intelectuales y políticos comenzaron a preguntarse por las causas de esa decadencia, y así forjaron un relato (que de mítico tenía mucho y de histórico muy poco) según el cual España como comunidad nacional existía desde el tiempo de los godos, había alcanzado la cumbre de su gloria durante el reinado de los Reyes Católicos y desde entonces no había hecho sino declinar ${ }^{6}$. En su imprescindible "Historia de las dos Españas", el profesor Santos Juliá proporciona numerosos ejemplos, extraídos de discursos políticos, que demuestran que ese relato está construido ya en los inicios del siglo XIX, se verá ratificado por la Guerra, y de una u otra suerte estará vigente durante siglo y medio más ${ }^{7}$.

Ese relato tuvo consecuencias decisivas para la construcción ideológica del constitucionalismo español. La primera Constitución europea había sido obra de los franceses, esto es, del invasor. Los principios que los liberales españoles quieren implantar en Cádiz, libertad, igualdad, uniformidad políticoadministrativa, son los mismos que rigen los destinos de Francia. En el contexto histórico en que se gesta nuestra primera Constitución, la Guerra de la Independencia, hubiera sido imposible declarar como paradigma de referencia el sistema político del país contra el que se libraba una guerra de "liberación". En esas circunstancias, el relato mágico sobre la decadencia de España y sobre su "luminoso pasado" desempeñó un papel fundamental. España no necesitaba recurrir a modelos foráneos porque le bastaba apelar a su historia pasada. En ella, en la Historia de España, se encontraban los principios de libertad y nueva organización que se querían implantar. No se trataba de inventar nada, sino de redescubrir unos principios que habían sido olvidados, y cuyo olvido había supuesto nuestra decadencia.

4 Tomas Y Valiente, F.: Manual de Historia del Derecho Español, Tecnos, Madrid, 1981, págs 561 y ss.

5 MuÑOz Machado, S.: El problema de la vertebración del Estado en España (Del siglo XVIII al siglo xxi). Iustel, Madrid, 2006, pág. 218.

6 La conexión de la decadencia del país con la liquidación de las instituciones históricas la formuló con gran éxito Francisco Martínez Marina. Todo se debió a la falta de continuidad de la obra de los Reyes Católicos. Martinez Marina, F. Teoría de las Cortes, Madrid, 1979. Influido por estas tesis, Jovellanos se mostró convencido de que nada hay de nuevo en los principios revolucionarios franceses que no se hubiera practicado ya en nuestros antiguos reinos

7 Julia, S.: Historia de las dos Españas, Taurus, Madrid, 2004, pág. 26 y ss. 
La lectura del Discurso Preliminar de don Agustín de Argüelles nos confirma cómo los principios de la Constitución de Cádiz pretenden fundamentarse en la tradición histórica ${ }^{8}$. La tesis que recorre ese discurso, desde el principio hasta el final, sostiene que el nuevo texto constitucional no hace sino formalizar las antiguas leyes fundamentales de España que habían caído en el olvido. El discurso afirma que la Constitución de 1812 poco tiene de novedoso. El objetivo pretendido por los hombres de Cádiz era "inyectar la sangre del siglo XVIII francés en los órganos de la vieja democracia castellana que el desuso atrofió o que cercenó el despotismo " ". Pero lo cierto es que la tradición de la "democracia castellana", en caso de que tal cosa hubiese existido alguna vez, quedaba muy lejos. Por el contrario, el ejemplo revolucionario francés era muy reciente y estaba en la mente de todos. Sin embargo, como la nación se había autodeterminado y reafirmado precisamente en su lucha contra Francia, prefería fundamentar en su tradición histórica, aunque ésta fuese más mítica que real, el nuevo régimen.

En definitiva, el eje del discurso consiste en negar que la obra constitucional suponga la introducción de principios o instituciones ajenos a la tradición histórica española ${ }^{10}$. Ello determinó que a diferencia de lo ocurrido en Francia, en España el nuevo régimen constitucional se construyera apelando a la Historia. En cierto sentido, la Historia era la fuente de la legitimidad del nuevo régimen. Tan singular contradicción no pudo dejar de provocar consecuencias indeseables.

Por lo que a nuestro tema se refiere, la apelación a la historia, motivada por las razones que se han expuesto, favoreció la continuidad de los regímenes forales de las provincias vascongadas y de Navarra. "iNo se apelaba a la historia como fuente de la nueva constitucionalidad? Pues historia eran, esen-

8 En la sesión del 22 de julio de 1811 la Comisión encargada de elaborar el proyecto de constitución acordó que el mismo debía ir acompañado de un discurso o preámbulo razonado que fuera digno de tan importante obra. Como consecuencia de tal decisión la Constitución de 1812 va precedida de un Discurso Preliminar que es, en palabras de Sánchez Agesta, un caso único en la historia del constitucionalismo universal: "Este discurso es algo más que un preámbulo, que por otra parte se redactó también al frente de la Constitución. Es un estudio analítico y persuasivo que señala la divisoria de dos regímenes políticos, pieza por pieza, con una reflexión separada para cada institución, con un examen de las causas que han corrompido esa imagen de un pasado y de los medios con que cabe restaurarlo y atemperarlo a nuevos tiempos y nuevas circunstancias y al adelantamiento de la ciencia del gobierno ". SANCHEZ AgESTA, L. "Introducción", en Argüelles, A. DE, Discurso Preliminar a la Constitución de 1812 , CEC, Madrid, 1981, pág. 25. SuAREz, F. Actas de la Comisión de Constitución, IEP, Madrid, 1976. Sesión de 22 de julio de 1811, pág. 146. El discurso fue elaborado principalmente por Agustín de Argüelles. Sobre este importante protagonista de nuestra historia constitucional y parlamentaria, SAN Miguel, E. Vida de don Agustín de Argüelles, 4 vol., Madrid, 1851. Remito al lector a mi comentario, TAJADura, J.: "El Discurso Preliminar de Agustín de Argüelles a la Constitución de Cádiz" en Pensamiento Constitucional, Año VIII, Núm. 8, Universidad Católica del Perú, Lima, 2001.

9 Fernandez Almagro, M. Orígenes del Régimen Constitucional en España, Editorial Labor, Barcelona, 1928, pág. 83.

10 "Nada ofrece la Constitución — son las primeras palabras del Discurso- en proyecto que no se halle consignado del modo más auténtico y solemne en los diferentes cuerpos de la legislación española". 
cialmente, los fueros, cuya conservación, al cabo, no era sino una coherente consecuencia del propio historicismo ideológico de la Constitución" ${ }^{11}$. Al invocarse la tradición como fundamento de la Constitución, resultó fácil para los defensores de las instituciones tradicionales forales apelar a esa misma tradición en su lucha contra los gobiernos centralistas liberales ${ }^{12}$. La tensión foralismo-liberalismo caracterizó así el siglo xix español y fue la causa de sucesivas guerras civiles (las guerras carlistas). Conflictos en los que pugnaban concepciones distintas sobre el principio de legitimidad del poder (liberal o teocrática).

Vemos así como en España, el establecimiento del régimen constitucional no supuso, en modo alguno, la desaparición de las instituciones forales propias del Antiguo Régimen ${ }^{13}$. Al finalizar la primera guerra carlista, se aprueba la Ley de 25 de octubre de 1839 por la que "se confirman los fueros de las Provincias Vascongadas y de Navarra sin perjuicio de la unidad constitucional de la monarquía". Se pone fin así a la controvertida polémica sobre su derogación o no por la Constitución gaditana. Dos leyes concretaron qué fueros permanecían en vigor. En primer lugar la Ley de 16 de agosto de $1841^{14}$, mediante la cual a Navarra se le aplicaba el mismo régimen jurídico que al resto de la Nación pero conservaba intacto su derecho civil y prerrogativas en materia administrativa, tributaria y militar. Con fundamento en esta Ley de 1841 (denominada paccionada) se estableció un primer Convenio Económico ${ }^{15}$. Y, en segundo lugar, el Decreto de 29 de octubre de 1841 por el que se suprimieron aspectos esenciales del régimen foral vasco aunque sin referencias ex-

11 Muñoz Machado, S.: El problema de la vertebración del Estado en España...ob. cit. pág. 219.

12 Teniendo en cuenta que la propia Constitución había apelado a la tradición histórica y había creado el mito de la recuperación de las viejas instituciones para incorporarlas al constitucionalismo, había establecido bases firmes no sólo para negar la contradicción existente entre Constitución y fueros, sino para crear "la ilusión de identidad" entre ambos. MARAVALL, J. A.: «El mito de la tradición en el constitucionalismo español" en Cuadernos Hispano Americanos, núm. 329-330, 1997, págs. 547 y ss. Ilusión que aun hoy permite al PNV sostener que "los derechos históricos son la única Constitución de los vascos".

13 Sobre el devenir histórico de la foralidad, véase el documentado y preciso estudio de Fernandez Segado, F.: "Disposición Adicional Primera” en Comentarios a la CE de 1978, (O. Alzaga, dir.) Edersa, Madrid, 1999. Tomo XII, págs. 520-544.

14 El Estatuto de Autonomía de Navarra (LORAFNA) se configura como una Ley de reforma y amejoramiento de la citada Ley de 1841 de modificación de los Fueros de Navarra.

15 Los foralistas navarros siempre han subrayado esta diferencia. El Convenio Económico navarro data de 1841, mientras que el Concierto Económico vasco tiene su origen en 1878. En todo caso, ambos configuran un sistema de financiación básicamente similar y que los respectivos Estatutos de Autonomía recogen como un "derecho histórico". Esta diferencia resulta irrelevante para las tesis que se defienden en este trabajo. La diferente historia de la foralidad vasca y navarra ha sido expuesta de forma clara por FERnAndez, T.R.: A partir de la ley de 1839 "el maximalismo se impuso en las provincias vascas, el famoso todo o nada impidió llegar a un arreglo en la cuestión de los Fueros tal y como había planteado o previsto la ley de 1839, en tanto que Navarra se arregló con las autoridades del Estado y de ahí salió la Ley Paccionada de 1841". Fernandez, T.R.: "Los derechos históricos de Navarra" en Derecho Público Foral de Navarra, AA.VV (Martin Retortillo, S. dir.), Pamplona, 1994, pág. 21. 
presas a las cuestiones de derecho civil, fiscales y militares. Ahora bien, gobiernos moderados posteriores restablecieron gradualmente las mismas instituciones que dicho Decreto había derogado.

Finalmente, hay que recordar que al término de la tercera guerra carlista en toda España se agudizaron las protestas contra el mantenimiento de los fueros. En ese contexto, la Ley de 21 de julio de 1876, abolitoria de los fueros, abordó expresamente los temas fiscales y militares. Lo que en Navarra fue en 1841, modificación de los fueros, en las Provincias Vascongadas se formuló como derogación. La oligarquía vasca aceptó la supresión del foralismo tradicional, por exigencia de la unidad constitucional, a cambio de conservar importantes privilegios en materia fiscal. De esta Ley surgieron los conciertos económico-fiscales. Aparentemente, la disputa por los fueros acaba con los conciertos económicos de 1878 (Real Decreto de 28 de febrero de 1878). Esta especialidad se justifica, como siempre, recurriendo a la tradición ${ }^{16}$. Pero lo que importa destacar es que, en realidad, la renuncia a los fueros fue el reducido precio (y digo reducido por su escasa relevancia en comparación con lo que se consiguió) que se pagó a cambio de una autonomía fiscal en donde la oligarquía vasca vio (con razón) grandes posibilidades. Y que condujo además al reconocimiento de otras potestades de orden administrativo ${ }^{17}$. Aparece así toda una gama de potestades fiscales y administrativas que configuran una "nueva foralidad" reivindicada con la misma fuerza que la antigua, aunque no procedía de los viejos fueros. Y subrayo esto para poner de manifiesto la inconsistencia de considerar en la actualidad dicha autonomía fiscal así consagrada como un "derecho histórico". En todo caso, ello es posible en la medida en que la nueva foralidad desemboca en un mito: el mito de los derechos históricos. Categoría esta que se incorpora al debate jurídico y político en la segunda década de la pasada centuria: "Procedente del mundo centroeuropeo - recuerdan Corcuera y García Herrera- su uso se extiende en relación con las reclamaciones nacionalistas que acabarían triunfando después de la Gran Guerra, y debió parecer un término expresivo que permitía a la reivindicación foral entroncar con planteamientos cuya legitimidad no parecía discutirse en la Europa de la época. Tras su primera utilización en 1917, el término acompañará al clásico de reintegración foral plena, que no adquiere por eso mayor concreción" ${ }^{18}$.

16 Como ha escrito Javier Corcuera, se acepta que no será la misma la exacción de las contribuciones, rentas e impuestos, en estas provincias que en las demás del reino, todo ello para respetar supuestas instituciones seculares correspondientes a una especial manera de ser social, política y económica. Lo cual quiere decir que se perpetúa un privilegio que beneficia además a las clases privilegiadas. Corcuera, J.: La patria de los vascos, Taurus, Madrid, 2001, pág. 82 y ss.

17 La Ley de 29 de junio de 1887 establece que "para el cumplimiento de las obligaciones anteriormente consignadas (en materia fiscal), las diputaciones de las tres provincias se consideran investidas no sólo de las atribuciones establecidas en la ley provincial, sino de las que con posterioridad al Real Decreto de 28 de febrero de 1878 han venido disfrutando"

18 Corcuera, J., y Garcia-Herrera, M.A.: La constitucionalización de los derechos históricos, CEPC, Madrid, 2002, págs. 37-38. La primera utilización del término en nuestro país probablemente tuvo lugar en el Mensaje que las Diputaciones de Alava, Guipúzcoa y Vizcaya dirigieron al 
Como acertadamente advierte uno de los más lúcidos estudiosos del nacionalismo vasco, el profesor Javier Corcuera, el Partido Nacionalista Vasco ha hecho de los derechos históricos el nuevo gran mito de la tradición nacional vasca ${ }^{19}$. Y, en la medida en que se trata de un mito, resulta políticamente irrelevante que dichos derechos existieran o no ${ }^{20}$. Baste con señalar que, como nos recordara el tristemente desaparecido profesor Tomás y Valiente: "No tenemos conocimiento de un mítico Derecho vasco. Nunca esos tres territorios formaron entre sí algún tipo de unidad o sociedad política. A lo largo de los siglos XI y XII los tres territorios pertenecieron, en oscilación propia de tierras fronterizas, a Navarra o a Castilla. Desde el siglo xIII, sin interrupción ni crisis alguna, fueron territorios incardinados dentro de la Corona de Castillla, diferenciados entre sí y dotados de regímenes jurídicos propios si bien muy castellanizados" ${ }^{21}$.

Sea de ello lo que fuere en el plano político e ideológico, lo cierto es que, desde una perspectiva jurídica democrática, los derechos históricos ni existen ni pueden existir, por la razón evidente de que en democracia, es el pueblo y sus representantes y no la Historia, la fuente de la legitimidad del poder y del derecho. Pero aunque esto sea así nuestro último constituyente incluyó una Disposición en virtud de la cual la Constitución de 1978 ampara y respeta los derechos históricos de los territorios forales. El profesor Alzaga destacó tempranamente que se trata del único caso en el Derecho Constitucional Comparado en que una Constitución moderna otorga un tratamiento de tamaña deferencia a los derechos históricos ${ }^{22}$. Y por lo que se refiere a nuestro Derecho Constitucional, absolutamente insólito, con la única salvedad de la Constitución de Bayona de 1808.

Gobierno de la Monarquía en 1917. Solicitan el restablecimiento de sus fueros "sin hacer dejación ni por un momento de los derechos históricos que se han invocado en todos los tiempos por las corporaciones que hablaron en nombre de Vizcaya, Guipúzcoa y Alava". TAmayo Salaberria, V.: Las autonomía vasca contemporánea. Foralidad y estatutismo, Vitoria, 1994.

19 Corcuera Atienza, J.: Politica y Derecho. La construcción de la Autonomía Vasca, CEC, Madrid, 1991, pág. 309 y ss.

20 Sobre el uso y abuso de la historia y sobre la invención de la misma en el proceso autonómico español, resulta sumamente sugerente y esclarecedor, Blanco, R.: Nacionalidades históricas y regiones sin historia, Alianza Editorial, Madrid, 2005.

21 Tomas Y VAliENTE, F.: "Raices y paradojas de una conciencia colectiva" en Escritos sobre y desde el Tribunal Constitucional, CEC, Madrid, 1993. Pág. 200. Véase también del mismo autor su ya clásico Manual de Historia del Derecho Español, Tecnos, Madrid, $4^{a}$ edición, 1983. Págs. 249262. Una de las características fundamentales de la Constitución política de la Monarquía en la España de los Austrias era, efectivamente, la diversidad de situaciones jurídicas existentes. Pero esa diversidad se produce en el seno de una unidad encarnada en el Monarca. El sistema foral del Antiguo Régimen nunca se planteó ni siquiera como posibilidad que los territorios forales pudieran ser titulares de soberanía alguna por la sencilla razón de que durante su vigencia, las diferentes provincias jamás pusieron en cuestión el origen divino del poder del monarca, y por ello su soberanía, una soberanía fundamentada en la legitimidad histórica y teocrática.

22 Alzaga, O.: La Constitución española de 1978 (Comentario sistemático). Ediciones del Foro, Madrid, 1978, pág. 978. 


\section{LA PROBLEMÁTICA RECEPCIÓN CONSTITUCIONAL DE LOS DERECHOS HISTÓRICOS: LAS ADVERTENCIAS DEL PROFESOR GARCÍA PELAYO.}

Cualquier reflexión jurídica sobre el significado y alcance de un concepto tan impreciso e indeterminado como el de "derechos históricos", debe comenzar, trayendo a colación la advertencia que el maestro García Pelayo realizó en el momento en que tan controvertida categoría estaba discutiéndose en la Constituyente y que, lamentablemente, ningún eco encontró en nuestra clase política.

Desde las páginas de El País, el que fuera después primer Presidente del Tribunal Constitucional ${ }^{23}$, denunciaba el colosal despropósito que supondría introducir un principio de legitimidad histórica en una Constitución normativa ${ }^{24}$. Las citas son largas, pero la indiscutible auctoritas de la que emanan, creo que justifican su transcripción. En el Proyecto Constitucional, señalaba García Pelayo "se emplea la denominación, extravagante en nuestra época, de los derechos históricos. Se trata, en efecto de una expresión anticuada, aparentemente en el espíritu de la escuela histórica del Derecho, cuyas tesis constituyeron una de las bases ideológicas de los movimientos tradicionalistas y reaccionarios del siglo pasado, frente a las tendencias racionalistas y progresistas ${ }^{25}$.

Siendo esto ya bastante grave, aun lo es más el hecho de que la noción de derechos históricos apela a una legitimidad no democrática y que, por tanto, difícilmente puede tener encaje en una Constitución racional-normativa: "Esta idea de los derechos históricos representa, en cualquiera de sus formas, la transferencia a entidades territoriales de los principios legitimistas formulados originariamente para las monarquías; representa la extensión a épocas completamente distintas del principio típico de la Edad Media de la superior validez 'del buen derecho viejo' frente al derecho nuevo, es decir, exacta-

23 El artículo apareció el Domingo 24 de septiembre de 1978: «El Proyecto Constitucional y los Derechos Históricos", y está recogido en sus Obras Completas. Garcia Pelayo, M.: Obras completas. CEC, Madrid, 1991. Vol. III, págs. 3171 y ss.

24 La mejor exposición sobre el concepto de Constitución racional-normativa sigue siendo la suya. Garcia Pelayo, M.: "Derecho Constitucional Comparado" en Obras Completas....cit. Vol. I, págs. 259 y ss.

25 También Laporta ha recordado recientemente la incompatibilidad de la noción de derechos históricos con la comprensión moderna del Derecho: "Para la comprensión radicalmente moderna del derecho como artificio humano es imposible la idea de "derecho histórico" que se va a proponer frente a él en todo el ámbito del pensamiento jurídico occidental en el tránsito del siglo XVIII al XIX, desde la reacción de Burke frente a los principios fundamentales de la revolución francesa, pasando por el tradicionalismo de Joseph de Maestre y el romanticismo comunitarista alemán, hasta la disputa de los juristas de la Escuela Histórica en torno a la necesidad de la codificación". LAPORTA, F.J. "LOS derechos históricos en la Constitución: algunos problemas teóricos" en Laporta, F.J. y SAIZ ARnaiz, A.: Los derechos históricos en la Constitución, CEPC, Madrid, 2006, pág. 15. Efectivamente, y como bien ha expuesto Fernández Sebastián, el fuerismo fue influido por autores y doctrinas heterogéneas entre las que, indudablemente, hay que incluir a De Maestre y Burke. Fernandez Sebastian, J.: La génesis del fuerismo. Prensa e ideas políticas en la crisis del Antiguo Régimen. Siglo XXI editores, Madrid, 1991, pág. 94. 
mente la inversión de los términos sobre los que se construyen los ordenamientos jurídicos modernos, en los que el derecho nuevo priva, normalmente, sobre el viejo; representa, en fin, la pretensión de sustituir la legitimidad racional por la legitimidad tradicional, pretensión que no tiene sentido cuando la tradición se ha interrumpido durante largo tiempo" 26.

Finalmente, y tras haber calificado a los mencionados derechos históricos como "privilegio sustentado sobre si mismo" ${ }^{27}$, el insigne constitucionalista, con gran lucidez, percibió los riesgos de reconocer algo tan «vago, difuso y confuso": "Esta ambigüedad básica es el comienzo de muchas más, abre paso a interpretaciones teóricas y prácticas de gravedad incalculable y, sobre todo, proporciona un arsenal de argumentos jurídicos que pueden ser esgrimidos, sea articulados en estrategias políticas audaces y de largo alcance, sea para finalidades más modestas - por ejemplo, destinadas a crear un ámbito privilegiado en materia fiscal o en otro campo- pero no por eso menos perturbadoras del sistema político y la vigencia del orden constitucional" ${ }^{28}$.

Obsérvese que, con una intuición que se ha demostrado acertada, el que fuera primer Presidente de nuestro Tribunal Constitucional puso claramente de manifiesto el carácter problemático de la categoría ${ }^{29}$. Y ello por dos razones.

26 Garcia Pelayo, M.: Obras completas. CEC, Madrid, 1991. Vol. III, págs. 3171 y ss.

27 El tenor literal de la Disposición Adicional según la cual la Constitución "reconoce" los derechos históricos "podría interpretarse en el sentido de que más allá de la Constitución, y, al parecer, con validez igual a ella, existe un círculo jurídico privativo, un privilegio sustentado sobre si mismo, unas inmunidades de los antiguos señoríos cuyo reconocimiento se considera como condición para la integración de las provincias vascas en el Estado español". GARCia PeLAYo, M.: Obras completas...ob.cit. Pág. 3174. Como es sabido el término "reconoce" fue finalmente reemplazado por el "ampara y respeta" lo que resulta indiferente a los efectos del referido comentario crítico. Lo relevante fue que tras el primer párrafo de la DAP se incluyó un segundo según el cual "la actualización general de dicho régimen foral se llevará a cabo, en su caso, en el marco de la Constitución y de los Estatutos de Autonomía".

28 Garcia Pelayo, M.: Obras completas...ob.cit. Pág. 3175. Más recientemente, y en la medida en que los redactores de los nuevos Estatutos de Autonomía han mostrado un enorme interés por la categoría que nos ocupa y preocupa, el profesor Sosa Wagner, en uno de los más lúcidos ensayos realizados sobre nuestro modelo de organización territorial, ha denunciado el absurdo que supone apelar a derechos históricos en el siglo xxI: "Hurgar en estos derechos históricos — escribe el ilustre Catedrático de Derecho Administrativo — nos lleva a los derechos contenidos en los fueros - como ocurre expresamente en el Estatuto de Valencia- que eran una amalgama de disposiciones de derecho privado y público, de las que sólo pueden sobrevivir en los tiempos modernos algunas de las primeras, difícilmente las segundas, pues serían incompatibles con las sacudidas revolucionarias que el derecho público en general ha experimentado desde finales del siglo xviII. En la idea de fuero anidaba la 'exención', la 'inmunidad' frente al poder, también la de 'pacto' o acuerdo con un señor que se comprometía a aceptar determinadas reglas y costumbres. Será pues un privilegio frente a la Corona que se estaba imponiendo como poder emergente y que dará como resultado el Estado. Por ello quien no acepta el régimen constitucional en el siglo XIX — el carlismo- se aferra a tales fueros para cobijar en su concha sus diferencias y no dejarse contaminar por el régimen constitucional, por las libertades, por la democracia y el sufragio, limitado primero, universal después". Sosa WaGner, F.: El Estado fragmentado, Trotta, Madrid, 2007.págs. 149-150.

29 Recientemente, el profesor Laporta en su sugerente estudio antes citado, ha situado el problema en su correcto contexto, "una pugna entre las dos grandes concepciones del derecho" 
Una intrínseca, por su incompatibilidad misma con el principio de legitimidad democrática en el que se fundamenta la Constitución racional-normativa. Y otra extrínseca, esto es, por los perturbadores efectos que de dicha inclusión podrían derivarse para el conjunto de nuestro sistema constitucional. Entre ellos cabría citar la instrumentalización de los derechos históricos al servicio de la secesión (tesis que de una u otra suerte defiende en sede doctrinal Miguel Herrero de Miñón y en sede política se ha plasmado en el denominado Plan Ibarrtexe defendido por el nacionalismo vasco soberanista) o la invocación de los mismos para lograr privilegios fiscales propios de un sistema confederal.

Si esto es así, ¿por qué estas acertadas observaciones no fueron atendidas? Constituiría un formidable ejercicio de falsificación de la realidad y de la historia el pretender negar que, si finalmente "los derechos históricos" fueron introducidos en la Constitución, ello se debió a la presión terrorista de ETA. Aunque esto es algo que resulta políticamente inoportuno recordar, como bien advierte Gil Calvo: «el dualismo de nuestro sistema autonómico, que reconoce la legitimidad de los conciertos forales, debe ser atribuido en buena medida a la espada de Damocles que sobre los constituyentes ejercía el chantaje terrorista" ${ }^{30}$.

En todo caso, la lectura de los diarios de sesiones de nuestras Cortes Constituyentes nos pone de manifiesto que en la discusión sobre la forma de organización territorial del Estado las apelaciones a la Historia fueron continuas y constantes por parte, sobre todo, de los representantes de las fuerzas políticas nacionalistas. El Partido Nacionalista Vasco fue el que llevó la cuestión foral a las Cortes Constituyentes ${ }^{31}$. Este partido sostenía (y sostiene) la tesis de que el régimen foral era la Constitución sustancial de los vascos. Para dar satisfacción a sus demandas se incorporaron al Texto Constitucional, la referida DAP y la Disposición Derogatoria Segunda ${ }^{32}$. Sin embargo, esta fór-

la racionalista y la historicista. "Aquella incompatibilidad de entonces (..) se perpetúa hoy también en dos lógicas subyacentes y dos precomprensiones del derecho que están en el orígen de todos nuestros desacuerdos". Y más adelante advertirá de la imposibilidad "de situarse en posiciones intermedias o sincréticas". LAPORTA, F.J. "Los derechos históricos en la Constitución...ob.cit, pág. 19 y 23. Ahora bien, esa pugna trasciende la idea de derecho, puesto que en ella subyace un conflicto entre principios de legitimidad. Y ese conflicto sólo puede resolverse con la victoria de uno de ellos.. También, sobre la oposición entre Constitución y fueros, Clavero, B.: Fueros Vascos. Historia en tiempos de Constitución, Ariel, Barcelona, 1985, pág. 75.

30 Gil Calvo, E.: "La deriva autonómica”...ob. cit. pág. 30. En el mismo sentido, el profesor Corcuera entiende la DAP como la huella dejada por el nacionalismo vasco en sus intentos de introducir una interpretación maximalista de los fueros en la Constitución. Huella que no podría explicarse sin la pervivencia del terrorismo y de su apoyo social. CORCUERA, J.: Política y Derecho. La construcción de la Autonomía Vasca, CEC, Madrid, 1991, pág. 279.

31 De forma un tanto sorprendente puesto que en junio de 1977 la dirección del PNV se había negado a impulsar una campaña en defensa de los fueros porque el "planteamiento y terminología empleados tal vez recuerdan a un perido ya superado como es el carlismo". CorCuERA, J.: "Consecuencias y límites de la constitucionalización de los derechos históricos en los territorios forales" en Revista Española de Derecho Constitucional, núm. 69, 2003, pág. 238.

32 "En tanto en cuanto pudiera conservar alguna vigencia, se considerará definitivamente derogada la Ley de 25 de octubre de 1839 en lo que pudiera afectar a las provincias de Alava, 
mula (debido al segundo párrafo de la DAP) no fue aceptada por el PNV quien no dio su apoyo a la Constitución de 1978. En el referéndum constitucional su lema de campaña fue: "Esta Constitución vulnera nuestros fueros: defiende los fueros: abstente" 33 .

En definitiva, desde un punto de vista político, la recepción constitucional de los derechos históricos sirvió, aparentemente, para muy poco. El propósito que se perseguía era integrar al nacionalismo vasco en el consenso constitucional y no se consiguió ${ }^{34}$. Treinta años después, podemos hacer un balance de lo que la referida DAP ha dado de sí. Y dicho balance, conviene subrayarlo con claridad, ha sido claramente negativo. Se trata de un precepto que no ha servido para resolver ningún problema político y que, por el contrario, ha creado muchos. Como con meridiana claridad y acierto pleno subraya Tudela Aranda, en un magnífico estudio sobre la cuestión: La DAP "no ha resuelto la inserción del País Vasco en el sistema constitucional y ha servido como alimento a otros conflictos. Por una parte, situó en una situación de posible privilegio a dos Comunidades Autónomas, lo cual inevitablemente tenía que contagiar a Cataluña; por otra, al legitimar en la Historia determinadas diferencias, junto con la Disposición Transitoria Segunda, fortalecía en otras Comunidades la sensación de agravio. La consecuencia no podía ser otra que la que ha sido: en una nueva redacción de los Estatutos de Autonomía, los derechos históricos se expanden más allá de sus fronteras naturales $" 35$.

Y es que, la buena fe del intérprete (constitucionalista) no puede impedir que la categoría de los derechos históricos desemboque, inevitablemente, en un conflicto político con quienes defienden una concepción historicista de los mismos. En este sentido, el profesor Laporta nos recuerda cómo "cuando en un determinado momento histórico y en un determinado ámbito geográfico, las presuposiciones del constitucionalismo y los postulados del historicismo como teoría jurídica no coinciden al señalar la naturaleza del sujeto colectivo y quienes son sus integrantes y fronteras, el conflicto político es inevitable. Podrá revestirse con el ropaje del derecho, con el ropaje de la historia o con

Guipúzcoa y Vizcaya. En los mismos términos se considerará definitivamente derogada la Ley de 21 de julio de 1876". La gran paradoja de esta disposición es la advertida por Javier Corcuera de que "en nombre de la Historia se pretendan anular ciento cuarenta años de historia".

33 Desde entonces el nacionalismo vasco no ha dejado de expresar su rechazo a una Constitución que simultánea y contradictoriamente reconoce los derechos históricos pero niega los derechos originarios del pueblo vasco. ¿No habría sido más honesto dejar claro en sede constituyente que la propia lógica constitucional impide que unos ciudadanos tengan mayores o mejores derechos que otros?

34 El propósito de la DAP era conseguir que los fueros dejaran de ser algo que por naturaleza se oponía a la Constitución. Así el profesor Solozábal habla de Constitucionalismo foral: SOLOZABAL, J.J.: "Derechos históricos, Constitución y soberanía" en Claves de Razón Práctica, núm. 107, 2000, pág. 38.

35 Tudela Aranda, J.: "La Disposición Adicional Primera y los nuevos Estatutos de Autonomía. La Historia como legitimación de la Autonomía" en Revista de Administración Pública, núm. 173, 2007, pág. 152. 
el ropaje de la sociología, pero se trata de un desacuerdo político fundamental sobre la identidad de los actores del juego" ${ }^{36}$.

Todos estos problemas políticos tienen su origen, en última instancia, en la propia naturaleza jurídica de la categoría que nos ocupa: una naturaleza antidemocrática, y, por ello mismo y aunque esta afirmación pueda sorprender, inconstitucional. Pero antes de desarrollar esta tesis, resulta obligado exponer someramente el desarrollo legislativo, y la interpretación doctrinal y jurisprudencial, de la DAP. Desarrollo que treinta años atrás nadie hubiera podido imaginar ${ }^{37}$.

En todo caso, dejo a un lado la crítica a la que cabe someter a la DAP, desde la perspectiva de la Teoría del Derecho. Crítica que se fundamentaría en estos dos argumentos: por un lado, la consideración como sujeto titular de derechos de entes colectivos: los territorios forales que acabarían convirtiéndose en el Pueblo Vasco o Navarro, implica una alteración sustancial de nuestra comprensión de la sociedad: "Se pierde de vista de golpe la complejidad de toda la realidad social: esos entes sociales holistas acaban por ser percibidos como objetos uniformes y monolíticos y con ellos se cierra el paso a toda comprensión de su dinamismo y diversificación interna" ${ }^{38}$. Por otro lado, resulta muy difícil de explicar la atribución de derechos subjetivos a esos entes colectivos. En el lenguaje popular se puede hablar de derechos del Pueblo Vasco o del Pueblo Navarro, pero en un discurso serio, desde una perspectiva técnico-jurídica, hay que utilizar el término "derecho" con más rigor del que habitualmente se hace. Me remito en este punto al estudio citado del profesor Laporta ${ }^{39}$.

36 Laporta, F. J.: “Los derechos históricos en la Constitución...ob.cit, pág. 24.

37 Corcuera, J y Garcia-Herrera, M.A.: La constitucionalización de los derechos históricos...ob.cit., pág. 216.

38 LAPORTA, F. J.: “Los derechos históricos en la Constitución...ob.cit, pág. 36.

39 "Los derechos son una técnica normativa que exige para ser usada con éxito de una muy precisa determinación de quién es su titular, quién los ejerce y cómo se les puede dar satisfacción. Es inútil conceder derechos a entidades indefinibles, pues no se pueden saber cuando se da el caso de que tales entidades están presentes, cuándo tienen esos derechos o cuándo carecen de ellos, así como tampoco se puede saber cómo y cuándo se ejercen. Además (...) todo derecho concedido correctamente a un grupo puede ser descompuesto conceptualmente en derechos individuales de los integrantes de ese grupo, en cuyo caso su existencia sería redundante. Por otra parte, cuando en la experiencia jurídica se conceden derechos a entidades colectivas se conceden siempre a entidades o instituciones, por ejemplo, las personas jurídicas (sociedades, asociaciones, fundaciones), que cumplen claramente con dos condiciones: tienen una identificación precisa e individualizada y han articulado normativamente en su interior algún mecanismo de representación que nos informa con precisión de cuándo la entidad colectiva actúa a través de sus órganos. Es decir, no se trata de pretendidos seres anteriores a las normas sino de personas 'artificiales' construidas por las normas del sistema jurídico". Las entidades defendidas por el historicismo (pueblos, naciones culturales o minorías) no satisfacen estos requisitos. Por ello no cabe atribuirles como tales entes colectivos ningún derecho. LAPORTA, F.J. "Los derechos históricos en la Constitución...ob.cit, pág. 38. 


\section{EL DESARROLLO DE LOS DERECHOS HISTÓRICOS EN LOS ESTATUTOS DE AUTONOMÍA.}

\subsection{La Singularidad de los Estatutos del País VASCO y NaVARRa.}

La recepción de los derechos históricos en la CE de 1978 singulariza la excepcionalidad de la autonomía política de los territorios forales ${ }^{40}$. La legitimidad de dicha autonomía se fundamenta en la propia DAP que va a permitir a Navarra convertirse en Comunidad Autónoma al margen de los procedimientos previstos; y, sobre todo, que va a permitir a Navarra y al País Vasco disfrutar de un techo competencial superior al del resto de las Comunidades, en la medida en que incluye la autonomía fiscal plena. El reconocimiento constitucional de un título histórico que introduce un plus de legitimidad a la autonomía política de los territorios forales se refleja en las singularidades que recogen los Estatutos del País Vasco y de Navarra. Y ello porque la DAP, guste o no, es una norma constitucional y, como tal, no ha dejado de producir efectos.

Los Estatutos de Autonomía del País Vasco y de Navarra se configuran como los instrumentos normativos de actualización de sus respectivos derechos históricos en virtud de lo dispuesto en el segundo párrafo de la DAP. Es cierto que la inclusión del segundo párrafo de la DAP (necesidad de actualizar los derechos históricos en el marco de la Constitución) es lo que, aparentemente, suscitó el rechazo del nacionalismo vasco. En este sentido, se ha dicho que este segundo inciso neutraliza los potenciales efectos perturbadores del reconocimiento de los derechos históricos. No creo que ello sea así. En primer lugar porque resulta jurídicamente incomprensible cómo se pueden actualizar "en el marco de la Constitución" unos derechos que la excepcionan. Y ello porque si se interpreta el sintagma "en el marco" en el sentido de que hay que reconducir la actualización de los derechos históricos a todos y cada uno de los preceptos de la Constitución, evidente resulta que la DAP quedaría vacía de contenido. Y, en segundo lugar, porque resulta políticamente ingenuo pensar que el resto de Comunidades Autónomas vayan a aceptar indefinidamente un dualismo en virtud del cual van a quedar relegadas a comunidades de "segunda categoría" debido a que sus Comunidades carecen del título "histórico" reconocido en la DAP.

Veamos en que se traducen esas singularidades, esto es, como se actualizan en los Estatutos de Autonomía los derechos históricos.

40 Considero innecesario exponer las diferentes razones que demuestran que según la Constitución sólo son titulares de los derechos históricos las provincias vascas y Navarra. Remito al lector al bien documentado y argumentado estudio de SAIZ Arnaiz, A.: "La titularidad de los derechos históricos y las reformas estatutarias" en LAPORTA, F.J. y SAIZ ARNAIz, A.: Los derechos históricos en la Constitución, CEPC, Madrid, 2006, págs. 97 y ss. Ahora bien, precisamente porque comparto sus planteamientos y premisas, discrepo de su conclusión sobre el artículo 5 del nuevo Estatuto de Cataluña que fundamenta el autogobierno y la posición singular de Cataluña en los derechos históricos. Para el profesor Saiz Arnaiz dicho artículo no incurre en inconstitucionalidad; para mí, por las razones que luego expondré, es inconstitucional. 
Por lo que se refiere al Estatuto vasco cabría señalar dos cuestiones: una relativa a la titularidad de los derechos históricos y otra a su contenido. El Estatuto de Autonomía del País Vasco de 1979, por su propia naturaleza fundacional creó un nuevo sujeto político, la Comunidad Autónoma del País Vasco. Y por lo que a nuestro tema se refiere, atribuyó la titularidad de los derechos históricos a ese nuevo sujeto, respetando a su vez los regímenes privativos de cada uno de las tres Provincias que integran la Comunidad. Ahora bien, aunque el contenido de los derechos históricos amparados por la DAP resulte ambiguo e indeterminado, lo que sí parecía claro era la cuestión relativa a quiénes eran los sujetos titulares de esos derechos, y evidente resulta que, por razones no ya políticas, sino de la más elemental lógica, entre esos sujetos no podían figurar quienes en el momento de aprobarse la citada Disposición no existían. Dicho con otras palabras, si la CA Vasca, como las dieciséis restantes, existe desde que se aprobó su respectivo Estatuto, dicha Comunidad no podía ser titular de derecho histórico alguno. Ahora bien, por razones políticas, se sacrificó la lógica, y con violación clara y manifiesta de la literalidad constitucional, se permitió atribuir a un nuevo sujeto, el pueblo vasco, la titularidad de los derechos históricos —-derechos que según la Constitución sólo corresponden a cada uno de los tres territorios, y habría que entender que como históricos son intransferibles puesto que en otro caso se rompe la misma tradición en que se fundamentan- con un enorme alcance ${ }^{41}$.

De la DAP se deducen, en el Estatuto Vasco, competencias como la enseñanza en toda su extensión, niveles o grados (art. 16), en materia institucional (art. 17) y, sobre todo, tributaria (art. 41). La reivindicación de una policía autonómica fue igualmente planteada y satisfecha en virtud del argumento foral ${ }^{42}$.

En todo caso, y comprender esto resulta fundamental, el proceso de elaboración y aprobación del Estatuto de Autonomía del País Vasco puso de manifiesto que, para buena parte de los representantes del Partido Nacionalista Vasco, los derechos históricos se identifican más con un acervo compe-

41 La Ley de 25 de noviembre de 1983, de Territorios Históricos, consagra la novación en la titularidad de los derechos históricos, olvidando el carácter inalienable de aquellos. Obsérvese que los fueros eran básicamente derecho local, y esa vinculación con las provincias o territorios determinaba su contenido. Difícilmente se podría atribuir el derecho a la autodeterminación a un ente local. Dicho con otras palabras, la taumatúrgica traslación de su titularidad afectará al contenido de los derechos, para ampliarlos. En todo caso, no deja de resultar paradójico el tenor claramente antihistoricista del Preámbulo de la Ley de Territorios Históricos: "Organizar el presente, garantizar la gobernabilidad de Euskadi en la actualidad, no es compatible con el modelo organizativo existente hasta 1839, o el sistema excepcional que derivó del primer Concierto Económico de 1878". A la vista de esta declaración del legislador autonómico vasco podríamos concluir que la DAP y la derogación de las leyes de 1839 y 1876 resultan por completo innecesarias. Pero no es así, la conclusión de aquel es que en realidad "el fondo de poder de la Comunidad Autónoma reside en sus Instituciones Comunes".

42 Fue el Gobierno de UCD quien para intentar evitar reivindicaciones similares por parte de los otros estatuyentes, aceptó que las competencias asumidas por el País Vasco en materia de policía autonómica, financiación, y educación se asumieran invocando directa o implícitamente la Disposición Adicional Primera de la Constitución. 
tencial indefinido y, por ello, potencialmente ilimitado, que con una lista precisa y cerrada de competencias. Esta concepción de los derechos históricos (que por razones evidentes resulta incompatible con la seguridad jurídica y con el carácter normativo de la Constitución) tiene su traducción jurídica en la Disposición Adicional Cuarta del Estatuto que dispone: "La aceptación del régimen de autonomía que se establece en el presente Estatuto no implica renuncia del Pueblo Vasco a los derechos que como tal le hubieran podido corresponder en virtud de su historia, que podrán ser actualizados de acuerdo con lo que establezca el ordenamiento jurídico". Ahora bien, en teoría, los potenciales efectos perturbadores del primer inciso de la disposición transcrita - en la que se vuelve a incidir en el papel de la Historia como fuente de derechos, sin precisar cuáles-, se ven, en cierta medida, neutralizados por el inciso final que, por exigir siempre y en todo caso, que la actualización de los derechos históricos se lleve a cabo "de acuerdo con el ordenamiento jurídico", impide entenderlos o interpretarlos como una norma abierta de límites indefinidos ${ }^{43}$. Pero el problema de fondo subsiste. Esta disposición configura al Estatuto como una norma provisional y abierta, susceptible en el futuro de desarrollar contenidos no enteramente subordinados a la Constitución desde un punto de vista material siempre que se respete el procedimiento de reforma estatutaria.

En el caso del Estatuto de Autonomía de Navarra (LORAFNA) debemos realizar las siguientes observaciones. En primer lugar, que no se plantea ningún problema respecto a la titularidad de los derechos históricos dada la unidad y la continuidad del sujeto, la provincia de Navarra. Ahora bien, aquí la cuestión controvertida (aunque obviamente carezca hoy ya de cualquier interés) es que Navarra entendió que la DAP le eximía de la necesidad de desarrollar su autogobierno siguiendo alguno de los procedimientos constitucionales. Dicho con otras palabras, Navarra se convirtió en Comunidad Autónoma al amparo de la propia DAP, esto es en virtud de sus derechos históricos. También en este caso, desde la lógica jurídica cabe denunciar la inconstitucionalidad de este proceder. Y ello porque la DAP no es en modo alguno una norma procedimental a cuyo través puedan crearse Comunidades Autónomas. El maestro Tomás y Valiente ya lo advirtió en su momento, aunque insisto en que se trata de un aspecto que en la actualidad carece por completo de trascendencia. Sea de ello lo que fuere, la especialidad del régimen autonómico navarro se hace depender de la DAP. Así el artículo 2 de la LORAFNA establece "Que los derechos originarios e históricos de la Comunidad Foral de Navarra serán respetados y amparados por los poderes públicos con arreglo a la ley de 25 de octubre de 1839, a la Ley Paccionada (sic) de 16 de agosto de 1841 y disposiciones complementarias, a la presente Ley Orgánica y a la Constitución, de conformidad con lo previsto en el párrafo primero de su DAP".

43 Solozabal EchaVarRia, J.J.: "Problemas constitucionales de la Autonomía Vasca” en Las bases constitucionales del Estado Autonómico, Mac Graw Hill, Madrid, 1998, pág. 344 y ss. 
Por otro lado, de esa singularidad el Estatuto va a derivar un régimen competencial determinado. El artículo 39. 1 a) establece que corresponden a Navarra todas las facultades y competencias que actualmente ejerce al amparo de lo dispuesto en la Ley Pacccionada de 16 de agosto de 1841. Entre las facultades o competencias con fundamento histórico foral cabe mencionar las comprendidas en los artículos 45 (fiscalidad), 461 a) y 2 (administración local), 48 (derecho civil foral), 49, 50 (función pública, contratación administrativa y otras), 51 (policía) y en cierta medida, en el artículo 53 (sanidad).

Además, hay que subrayar que el estatuyente navarro hizo suya la interpretación del vasco sobre el carácter potencialmente ilimitado en cuanto a su contenido de los derechos históricos e incluyó una disposición adicional relativa a la no renuncia de "cualesquiera otros derechos originarios e históricos que pudieran corresponder a Navarra" y que podrán incorporarse al ordenamiento "en su caso, conforme a lo establecido en el artículo 71" que es el que regula la reforma de la LORAFNA.

En este contexto, lo que me importa subrayar es que en ambos Estatutos (y sin que ello haya sido objeto de impugnación alguna) se reconoce que $\mathrm{Na}$ varra y el País Vasco, en virtud de su Historia, disfrutan de unos fantasmagóricos derechos a cuya titularidad y ejercicio no renuncian. Dicho con otras palabras, se introduce con total claridad el principio (inconstitucional) de legitimidad histórica. Y con ese fundamento, los juristas forales tratan de consolidar la idea de que la autonomía vasca y navarra tiene un fundamento distinto a las demás, esto es, diferente a la voluntad del Pueblo español, ese fundamento es la Historia. Se trata de una autonomía "preconstitucional" o "paraconstitucional" que, como tal, está por encima del Poder Constituyente. Baste, por todos, recordar las tesis de Herrero de Miñón, el autor que con mayor brillantez ha defendido las tesis que aquí se combaten: "Ante la Constitución, los derechos históricos son un a priori material caracterizado por la pre y para constitucionalidad". De lo que se deduce que existirían aunque la Constitución no los hubiera reconocido y que son un límite material al poder de reforma constitucional ${ }^{44}$. Según esta construcción, no es que la Constitución fundamente la foralidad, sino que los fueros legitimados por la Historia son los que sirven de fundamento a aquella: "El derecho a la autonomía de

44 Herrero De Miñon, M.: Derechos Históricos y Constitución, Taurus, Madrid, 1998, págs. 19-20. De ahí que encuentre en ellos el fundamento del derecho de autodeterminación: "Los derechos históricos requieren y posibilitan una autodeterminación paccionada. Esto es, haciendo que los terceros reconozcan y garanticen la autodefinición, autodelimitación y autodisposición de la propia personalidad política". "Autodeterminación y Derechos históricos" en Derechos Históricos y Constitucionalismo útil: Herrero, M., y Lluch, E. (eds.) Crítica, Barcelona, 2001, pág. 215. No es la menor de las contradicciones del pensamiento (presuntamente antipositivista) de Herrero el hecho de que si de verdad considera que los derechos históricos existen como algo previo, lógica y cronológicamente, a la Constitución, centre toda su atención en su reconocimiento por el derecho positivo vigente hasta el punto de dar por bueno que un simple Decreto Ley, 18/1977 de 14 de marzo, sirva para iniciar un proceso de 'novación' de la titularidad de los derechos históricos. 
Cataluña, como los derechos históricos de los territorios forales, preceden a la Constitución y por eso la fundamentan" ${ }^{45}$.

El Poder Constituyente (el Pueblo español), se afirma, no podría no haber reconocido los derechos históricos (la singular autonomía vasca y navarra) puesto que el Pueblo español está subordinado, sometido, a la Historia, suprema fuente de legitimidad. Fácilmente se comprueba que se trata de una tesis incompatible con la doctrina del Poder Constituyente del Pueblo que fundamenta la Constitución racional-normativa. Así lo entiende también el Tribunal Constitucional, quien en su decisiva sentencia 76/1988, se pronunció sobre el alcance y los límites de los derechos históricos reconocidos en la DAP de la Constitución. En el Fundamento Jurídico tercero el Tribunal subrayó que no es la Historia sino el Poder Constituyente el que otorga validez y vigencia a los mencionados derechos: "La Constitución no es el resultado de un pacto entre instancias territoriales bistóricas que conserven unos derechos anteriores a la Constitución y superiores a ella, sino una norma del poder constituyente que se impone con fuerza vinculante general en su ámbito, sin que queden fuera de ella situaciones 'históricas' anteriores. En este sentido, y desde luego, la actualización de los derechos históricos supone la supresión, o no reconocimiento, de aquellos que contradigan los principios constitucionales. Pues será de la misma Disposición Adicional primera y no de su legitimidad histórica, de donde los derechos históricos obtendrán o conservarán su validez y vigencia".

El Tribunal defiende así la supremacía normativa de la Constitución y del principio democrático pero no resuelve el problema de fondo. El Tribunal afirma que el fundamento de la validez y vigencia de los derechos históricos reside en la propia Adicional Primera y no en su legitimidad histórica, pero el problema reside en que la disposición constitucional citada recoge precisamente ese principio de legitimidad ${ }^{46}$. En definitiva, lo que el Tribunal Cons-

45 Herrero De Miñon, M.: Derechos Históricos y Constitución... ob.cit, pág. 24. "La filosofía política que inspira el entramado foral — subrayan Corcuera y García Herrera- puede resumirse esencialmente, en la afirmación de la soberanía originaria de los territorios forales, el carácter pactado (pacto foral) de la incorporación de dichos territorios a la Corona y el vínculo de unión personal (en la persona del Rey) como único lazo existente entre tales territorios vascos y los demás de la Monarquía". Corcuera, J., y Garcia-Herrera, M.A.: La constitucionalización...ob. cit. pág. 14. Esta es la tesis que defendió y defiende el que fuera portavoz de los Senadores Vascos en la Constituyente, Mitxel Unzueta: "Ese derecho originario, que en su núcleo primordial es un poder constituyente, en la medida en que define y pacta su propia condición, es el que constituye la esencia del derecho histórico. No es un derecho derivado de la historia, sino una realidad consagrada por la voluntad de los vascos a lo largo de su historia. Es una cuestión de legitimidad y no una disputa sobre competencias como con tanta frecuencia se insiste (...) No se trata de discutir una competencia determinada(...)Se trata de "ser" y ser reconocida esa identidad (...) El derecho histórico es hoy un principio legitimador de la exigencia del reconocimiento de ese ser". El CORREO, 18-II-2002. Como resulta evidente, a pesar de lo que digan Herrero y Unzueta, lo cierto es que "tener derecho a ser" es una expresión carente de sentido jurídico alguno: si un sujeto "es" no le hace falta tener un derecho a ser porque ya es y si no es, no puede ser titular de derecho alguno.

46 "La recepción constitucional de los derechos históricos implica una transformación de su fundamento: su validez y vigencia reposa en el texto constitucional y no en la legitimidad histó- 
titucional sostiene es que el constituyente, si hubiera querido, hubiera podido no recoger los derechos históricos en la Constitución. El constituyente no estaba obligado a reconocer esa categoría, pero puesto que sí lo ha hecho, ahora los derechos históricos se fundamentan también en la legitimidad democrática de la Constitución, y, en consecuencia, se imponen a los poderes constituidos. El Tribunal no se plantea la contradicción subyacente en esa tesis. Contradicción que consiste en derivar del principio de legitimidad democrática, principios de legitimidad incompatibles con aquella. Y es que sirve de muy poco proclamar que la voluntad del pueblo prevalece sobre la Historia en el momento constituyente, si se acepta que una vez promulgada la Constitución, los derechos históricos (por imperativo constitucional) limitan el alcance del principio democrático.

El Tribunal Constitucional de esta forma reconoce la vigencia del principio de legitimidad histórica en el marco de la Constitución. Frente a ese razonamiento contradictorio, entiendo que cualquier disposición (estatutaria o incluso constitucional, como es el caso de la DAP) que de cobertura jurídica a ese principio político (legitimidad de la historia y subordinación de la voluntad de los ciudadanos a aquella) se opone al principio de soberanía popular (art. 1.2 CE) y por ello, como expondré después, debe ser reputado inconstitucional.

Hemos de recordar también que, aunque, como hemos visto, de los debates constituyentes se deduce que los titulares de los derechos históricos amparados por la DAP de la Constitución son únicamente las Provincias Vascas y Navarra, (aunque Miguel Herrero en su interpretación de la categoría de derechos históricos los extiende a Cataluña y a Galicia) también el Estatuto de Aragón contiene una referencia a aquellos. Referencia que, en todo caso, no ha tenido consecuencias jurídicas ${ }^{47}$. Sea de ello lo que fuere, sorprende en todo caso "la ligereza con la que el legislador orgánico del Estado asumió una remisión a la DAP cuyos posibles efectos y (seguros) titulares eran ya de sobra conocidos" al aprobarse el Estatuto ${ }^{48}$.

Precisado el problema fundamental, procede examinar ahora el alcance y las consecuencias de las citadas disposiciones estatutarias del País Vasco y Navarra. En el caso del País Vasco, las teorías y doctrinas de quienes, operando con el principio monárquico, defienden la soberanía originaria de determinados territorios ${ }^{49}$, y la aplicación práctica de aquellas concretada, por ejem-

rica, que no puede operar con independencia de las normas jurídicas que proceden a la actualización de los derechos históricos". Corcuera, J., y Garcia-Herrera, M.A.: La constitucionalización...ob. cit. pág. 80.

47 La Disposición Adicional Quinta del Estatuto de Autonomía de Aragón reproduce las previsiones de los estatutos vasco y navarro sobre la no renuncia a los derechos que como tal le hubieran podido corresponder en virtud de la historia al pueblo aragonés. Los efectos de esa disposición han sido, hasta la fecha, nulos. Entre otras cosas porque el propio Estatuto (a diferencia del vasco y del navarro) no se configura como marco para la actualización de derecho histórico alguno.

48 SAiz ARnaiz, A.: “La titularidad de los derechos históricos y las reformas...ob. cit., pág. 120. 49 Esa es la tesis de M. Herrero: "en (los derechos históricos) se expresa el carácter originario de una personalidad inderogable que ha de decidir democráticamente (puesto que es el 
plo, en el Plan Ibarretxe, nos han puesto de manifiesto que los temores de don Manuel García Pelayo no eran, en modo alguno, infundados. Entre los derechos históricos y originarios del Pueblo Vasco al que este no ha renunciado, figuraría el de autodeterminación mediante secesión de España ${ }^{50}$. Por lo que se refiere a estas pretensiones de fundamentar en los derechos históricos la soberanía vasca y el derecho de autodeterminación baste con señalar que la jurisprudencia constitucional y la doctrina mayoritaria rechazan, con rotundidad y contundencia, ese tipo de construcciones. En la medida en que el derecho de autodeterminación no sólo no fue admitido por el Constituyente, sino que fue objeto de su expreso rechazo, resulta un despropósito pretender buscarle cualquier tipo de encaje constitucional.

Dejando a un lado, por tanto, esta interpretación en clave soberanista, en un excelente estudio sobre este tema, los profesores Corcuera y García-Herrera destacan como "la virtualidad de la actualización de los derechos históricos ha permitido poner en marcha peculiaridades que no podían imaginarse al aprobarse el Estatuto" " ${ }^{51}$. Y es que efectivamente, el desarrollo de la DAP ha tenido una trascendencia muy superior a la que parecía estar llamada a tener. Ello ha sido posible a partir del entendimiento de la DAP no sólo como una norma concreta con contenido determinado sino como un principio general de contenido potencialmente inagotable (lo que de una u otra suerte se recoge en las Disposiciones Adicionales de los Estatutos vasco y navarro). En este contexto, y como acertadamente advierte Tudela Aranda, "no puede sino sorprender el poco hincapié realizado sobre la necesidad de subordinar la actualización del régimen foral a lo dispuesto en la Constitución" 52 .

\subsection{LOS «PRIVILEGIOS» FISCALES.}

El reconocimiento constitucional de los derechos históricos de los territorios forales - dejando a un lado los intentos de fundamentar en ellos el derecho de autodeterminación y la existencia de una soberanía originaria- para lo que ha servido en la práctica es para dar cobertura a un singular sistema de financiación autonómica para los dos Comunidades titulares de dichos derechos, Navarra y el País Vasco, diferente del general o común aplicable a las

pueblo el titular de tales derechos y no ya los territorios forales) y que se relaciona paccionadamente con terceros", Herrero, M.: Encuesta sobre el Derecho de Autodeterminación en Teoría y Realidad Constitucional, núm. 10-11, 2002-2003. pág. 78.

50 En otro lugar he analizado con detalle esta problemática, TAJADURA, J.: "Derecho de Autodeterminación" en El Estado Autonómico. Integración, solidaridad y diversidad (VIDAL, J.M y Garcia-Herrera, M.A, coord.), INAP-Colex, Madrid, 2005, Vol. II, págs. 177-206.

51 Garcia Herrera, M.A. y Corcuera, J.: La constitucionalización de los Derechos históricos...ob.cit., pág. 118.

52 Tudela Aranda, J.: “La Disposición Adicional Primera y los nuevos Estatutos de Autonomía... ob.cit., pág. 165. 
otras quince Comunidades, y en virtud del cual disfrutan de un nivel de financiación muy superior al resto ${ }^{53}$.

De un atento examen a los debates constituyentes, los profesores Corcuera y García Herrera han concluido que «en ningún momento pareció dudarse de que el reconocimiento de los Derechos Históricos implicaba reconocer y mantener los restos de la foralidad subsistente (convenio navarro y concierto económico alavés, que lógicamente había de extenderse a Vizcaya y Guipúzcoa)" 54 .

La interpretación que se ha impuesto de la DAP es la defendida por el profesor Tomás Ramón Fernández que la considera una "garantía institucional" de los derechos históricos ${ }^{55}$. Y a partir de ella, se ha entendido (sin mayor debate jurídico) que la singularidad fiscal formaría parte de la mencionada garantía institucional. Pero, obsérvese que, en contra de lo que pudiera parecer, el modelo de financiación foral no se encuentra recogido expresamente en la Constitución. Ha sido deducido como un derecho histórico ${ }^{56}$,

53 En este sentido y en relación al debate sobre la simetría o asimetría de nuestro sistema autonómico el profesor Corcuera acertadamente advierte lo siguiente: "La igualdad es jurídicamente difícil y políticamente inviable, pero no ya por el juego de la distinción entre nacionalidades y regiones, sino de resultas de la efectividad que ha tenido la Disposición Adicional Primera de la Constitución, particularmente en lo relativo al Concierto Económico del País Vasco o al Convenio Navarro". Corcuera, J.: "La distinción constitucional entre nacionalidades y regiones en el décimoquinto aniversario de la Constitución" en Documentación Administrativa, núm. 232-233, 1992-93, pág. 22. Indiscutiblemente, se trata de la singularidad foral de mayor trascendencia: "Gracias a la sobrefinanciación que permite, los órganos comunes de la Comunidad Autónoma Vasca tienen mucha más disponibilidad de recursos que las otras Comunidades a la hora de realizar sus políticas ordinarias". Lo mismo es aplicable a la Comunidad Foral de Navarra. CORCUERA, J., y GARCIA-HERRERA, M.A.: La constitucionalización... ob. cit., pág. 83. Sobre el sistema financiero foral MEDINA GUERRERO, M.: Los regímenes financieros forales en la Constitución de 1978. IVAP, Oñate, 1991.

54 Corcuera, J., Y Garcia-Herrera, M.A.: La constitucionalización...ob. cit. Pág. 22. Y ello a pesar de que el concierto económico tuviera su origen en la abolición de los Fueros. Sin embargo, como advierte Laporta, se trata de una institución que "al margen de su pingüe significado económico tiene el mismo 'espíritu', el mismo sabor, que los fueros: competencias provinciales, inmunidades fiscales y pacto con la Hacienda estatal. LAPORTA, F.J. "Los derechos históricos en la Constitución...ob.cit, pág. 31. Quizás ello explique, políticamente, aunque no jurídicamente, cómo algo que se concedió en lugar de los fueros pudo convertirse en un derecho histórico de la Comunidad Autónoma Vasca.

55 FERnANDEZ, T. R.: Los derechos históricos de los territorios forales, Civitas, Madrid, 1985. En un reciente estudio el profesor Laporta ha rechazado la validez de la teoría de la garantía institucional que necesariamente parte de entender en sentido fuerte, esto es como obligación, la normatividad de la DAP. Para este autor, la DAP sería una norma meramente permisiva que no impone obligación alguna. Se trata de una norma "que permite a las autoridades competentes diseñar el orden jurídico de la autonomía vasca inspirándose en contenidos materiales o aspectos estructurales del histórico régimen foral, debidamente actualizados y siempre que no pugnen con preceptos constitucionales". Además, la teoría de la garantía institucional de la foralidad tiene un flanco débil,: "Es que hay alguien que haya estudiado en serio la foralidad que piense todavía que después de siglo y medio de alteraciones hay algo así como su núcleo o médula". LAPORTA, F.J.: "Los derechos históricos en la Constitución...ob.cit., págs. 83 y 63.

56 A pesar de que se trate de un instituto ajeno al régimen foral y que trae causa de la ley de 1876, abolitoria de los fueros, y derogada por la Disposición derogatoria segunda de la Constitución. 
pero para que tal deducción fuera legítima tendrían que haber operado los límites constitucionales, en este caso, los principios de igualdad y solidaridad. Sólo en la medida en que dicho modelo fuera compatible con dichos principios podría haber sido asumido como una actualización de los derechos históricos. Recordar que la DAP no menciona ni el sistema de concierto ni el de convenio económico no es una cuestión banal. Si se demostrase su incompatibilidad con el principio constitucional de solidaridad (art. 2, $138 \mathrm{CE}$ ) - lo cual a la vista de diferentes estudios económicos de toda solvencia no es una tarea demasiado complicada- el sistema de financiación foral podría - y debería- ser suprimido por el legislador positivo (Cortes Generales) sin necesidad de reformar la Constitución. El mismo resultado podría ser alcanzado por nuestro legislador negativo (Tribunal Constitucional).

En el FJ cuarto, de la STC 76/1988, el Tribunal hace suyas la tesis del profesor Tomás Ramón Fernández sobre el carácter de garantía institucional de la DAP. Así, al rechazar la tesis de que los derechos históricos sean un título competencial autónomo, afirma: "La idea de derechos históricos no puede considerarse como un título autónomo del que puedan deducirse específicas competencias. Lo que la Constitución ha venido a amparar y respetar no es una suma o agregado de potestades, facultades o privilegios, ejercidos históricamente, en forma de derechos subjetivos de corporaciones territoriales, susceptibles de ser traducidos en otras tantas competencias, de titularidad o ejercicio respaldadas por la Historia. Como resulta de la misma dicción del párrafo segundo de la Disposición Adicional primera CE, lo que se viene a garantizar es la existencia de un régimen foral, es decir, de un régimen propio de cada territorio histórico de autogobierno territorial, esto es de su 'foralidad' pero no de todos y cada uno de los derechos que históricamente la hayan caracterizado ${ }^{57}$. El singular sistema de financiación del País Vasco y de Navarra es, según la doctrina mayoritaria, un elemento esencial de la foralidad constitucionalmente garantizada.

Este sistema consiste básicamente en que el País Vasco y Navarra tienen su propio sistema tributario. A sus instituciones competentes corresponde la facultad de mantener, establecer y regular, dentro de su territorio, su régimen fiscal. El artículo 40 del Estatuto vasco dispone que "para el adecuado ejercicio y financiación de sus competencias, el País Vasco dispondrá de su propia Hacienda Autónoma" y "las relaciones de orden tributario entre el Estado y el País Vasco vendrán reguladas mediante el sistema tradicional de Concierto

57 En definitiva, según el Alto Tribunal, el contenido y alcance de los Derechos Históricos debe concretarse en el Estatuto de Autonomía siempre dentro del marco constitucional. Lo que no pueden nunca es ser entendidos como un cauce para la apertura ilimitada del Texto Constitucional. Tal entendimiento resultaría incompatible con la normatividad de la Constitución, habida cuenta que permitiría al legislador autonómico decidir sobre su ámbito competencial legitimándolo en la Historia. El Tribunal no acepta que las competencias tengan un origen histórico sino que, una vez actualizadas por las vías legales, se puede acudir a los antecedentes históricos para precisar su contenido. SSTC 86/1988, 214/1989, 140/1990, 159/1993, 148/2006 y 195/2006. 
Económico o Convenios". En el caso de Navarra, el artículo 45 de la LORAFNA establece que: "1. En virtud de su Régimen Foral, la actividad tributaria y financiera de Navarra se regulará por el sistema tradicional del Convenio Económico. 2. En los Convenios Económicos se determinarán las aportaciones de Navarra a las cargas generales del Estado señalando las cuantías de las mismas y el procedimiento para su actualización, así como los criterios de armonización de su régimen tributario con el régimen general del Estado".

Los derechos históricos del País Vasco y de Navarra han introducido así un importantísimo y perturbador factor de asimetría en nuestro modelo de Estado Tan importante como único. Que afecta, en primer lugar, a la homogeneización del techo competencial, en la medida en que no resulta posible extender las facultades normativas en materia fiscal al resto de Comunidades Autónomas; y, en segundo lugar, como es obvio, impide constitucionalizar un sistema común de financiación de las Comunidades Autónomas. Se trata de una asimetría que, en definitiva, afecta negativamente a la solidaridad nacional, a la igualdad de los ciudadanos, y al Estado Social considerado en su conjunto.

En todo caso, esto es lo que explica que, desde hace años y hasta el momento de redactar estas líneas, el debate político sobre la financiación del Estado Autonómico gire inevitablemente en torno a la pretensión de algunas Comunidades de articular sistemas que les confieran niveles de financiación similares al País Vasco o Navarra. No debemos olvidar que la primera demanda de los impulsores de la reforma estatutaria catalana fue la de obtener un sistema de financiación que garantizase un resultado similar al vasco o navarro. Y que antepusieran ese tema a cualquier otra reivindicación competencial. Ahora bien, los economistas nos han advertido ya de que la generalización del sistema vasco y navarro supondría la quiebra fiscal del Estado. Se reconozca o no expresamente, lo cierto es que todo el proceso de reformas territoriales de la pasada Legislatura se ha desencadenado debido al descontento de ciertas Comunidades, Cataluña de manera singular, con el sistema de financiación vigente. Por ello no creo que sea exagerado afirmar que aquí se encuentra una de las claves fundamentales de nuestro problema territorial. Desde el punto de vista material, la dualidad del sistema vigente (el común para quince CC.AA y el foral para País Vasco y Navarro) supone una quiebra grave y manifiesta del principio constitucional de solidaridad.

Frente a esta situación, se ha dicho que lo inconstitucional no es el sistema foral de financiación (convenio/cupo o concierto/aportación) sino su aplicación práctica ${ }^{58}$. Dicho con otras palabras, que incrementando la apor-

58 Los informes del Instituto de Estudios Fiscales sobre financiación del Estado Autonómico ponen claramente de manifiesto la sobrefinanciación que disfrutan las Comunidades forales. El País Vasco, dado como fue calculado el cupo, obtuvo una sobrefinanciación equivalente al 3,4\% de su PIB (Diferencia entre su financiación 14.7 \% del PIB y la de las demás Comunidades, 11.4 \%). ¿De dónde sale esa sobrefinanciación? La respuesta es simple: es el coste de la solidaridad interautonómica en que el País Vasco no participa. La situación es similar en el caso de Navarra. Ruiz SoroA, J.M. El País, 15 de noviembre y 8 de diciembre de 2007. Esto es, a los ciudadanos 
tación del País Vasco y Navarra a las cargas estatales podría restablecerse la solidaridad. Se trata de una tesis políticamente oportuna y quizás más conveniente que la que aquí se mantiene. Pero ello no puede hacernos olvidar que desde una perspectiva jurídico-constitucional estricta, lo que repugna al principio democrático y a la solidaridad, no son sólo los efectos o las consecuencias del modelo foral, sino su propia configuración. Configuración que hace imposible la articulación de España como un Estado federal viable.

Llegados a este punto, en el que creo haber demostrado que no estamos ante un problema meramente teórico sino real, la tesis que después expondré rechaza este planteamiento de la cuestión. El problema constitucional que plantea la existencia de los 'privilegios fiscales forales' no es sólo el de que sus efectos o consecuencias sean inconstitucionales por atentar contra el principio de solidaridad. El problema es de mucha mayor gravedad. Es el fundamento mismo del sistema (y no sólo sus efectos), esto es la propia categoría de derechos históricos la que resulta incompatible con la Constitución.

\section{EL FORTALECIMIENTO DEL HISTORICISMO EN LA REVISIÓN DEL ESTADO AUTONÓMICO.}

De lo expuesto hasta ahora se deduce con claridad que, además de haber logrado un privilegiado sistema de financiación, el reconocimiento constitucional de los derechos históricos ha servido al nacionalismo vasco (y a ciertos sectores del foralismo navarro) para tratar de consolidar la no por falsa menos peligrosa idea de que la autonomía vasca (y la navarra para los juristas forales) se fundamenta en un título diferente a la Constitución. Esto es que la fuente de legitimidad es otra distinta del sujeto constituyente (el Pueblo español).

Lo que resulta sumamente preocupante, aunque es perfectamente comprensible e incluso previsible, es que el lenguaje historicista empleado por los estatuyentes vasco y navarro haya sido adoptado por la mayor parte de los estatuyentes durante el proceso de reformas estatutarias llevado a cabo durante la VIII Legislatura. Junto al relato mágico consistente en idealizar el régimen político foral como un antiguo escenario de libertad y de armonía entre todos los vascos (o entre todos los navarros) tenemos ahora numerosos relatos sobre la Historia de infinidad de pueblos peninsulares que llevan siglos luchando por la libertad y por la igualdad y unidos por profundos lazos de solidaridad colectiva. Los Preámbulos de los nuevos Estatutos han sido el lugar de acogida de estas narraciones míticas.

Este fenómeno es preocupante en la medida en que el principio de legitimidad histórica, inicialmente introducido por el Constituyente (DAP) con un carácter excepcional, se expande ilimitadamente. Ya no son sólo el País Vasco y Navarra los que buscan fundamentar o legitimar su autonomía en títulos

vascos y navarros a pesar de vivir en regiones avanzadas les corresponde más recursos por habitante que a los de otras Comunidades menos desarrolladas. En esto consiste la solidaridad foral. 
distintos a la voluntad del pueblo español, sino que lo mismo pretende, por ejemplo, Cataluña. Ahora bien, se trata de un proceso perfectamente previsible en la medida en que al haberse percatado el resto de las Comunidades Autónomas de la ventajosa situación de Navarra y del País Vasco y de que esa situación obedece a un privilegiado sistema de financiación cuyo fundamento no es otro que la Historia, nada de extraño tiene que aquellas quieran apelar también a la Historia. Dicho con otras palabras, la apelación a la legitimidad histórica ha permitido a dos Comunidades Autónomas disfrutar de unos privilegios, $\mathrm{O}$, aun concediendo que no sea un privilegio, de un singular sistema de financiación ${ }^{59}$. Es lógico que aquellos que pretenden disfrutar del mismo recurran por tanto, también, al discurso historicista ${ }^{60}$.

La legitimación de las diferencias entre Comunidades en virtud de la Historia ha sido una constante en la evolución del Estado Autonómico y ha sido la causa de su fracaso en el empeño de consolidarse como un Estado Federal basado en el insoslayable principio de igualdad entre sus miembros. Desde esta perspectiva, y ese es otro de sus perturbadores efectos sobre el sistema, la DAP impide consolidar nuestro Estado Autonómico como Estado Federal. De hecho, introduce el principio confederal (pactista) para las dos Comunidades titulares de Derechos Históricos y de esta forma, ha producido una sensación de agravio en el resto de Comunidades, generadora de una espiral reivindicativa cuya traducción son los nuevos Estatutos de Autonomía (Valencia, Cataluña, Andalucía y otros). Los rasgos confederales del modelo de Estado resultante de los nuevos Estatutos han sido denunciados por la mejor doctrina (Muñoz Machado, Sosa Wagner).

"Una mirada al desarrollo constitucional —escribe con meridiana claridad y acierto pleno Tudela Aranda - y más con los textos de reforma estatutaria encima de la mesa, lleva a la conclusión nítida de que la concepción racionalista ha sido incapaz no ya de ganar la batalla, sino, al menos de establecer unas coordenadas mínimas. La interpretación historicista ha ganado adeptos en cuanto ha permitido la consecución paulatina de mayor autonomía. Y sobre todo, en cuanto se vislumbra como fuente inacabable cuantitativa y cualitativamente para la reivindicación territorial. En este sentido, la aparición del pueblo como sujeto colectivo de derechos y heredero de toda una historia de grandeza y agravios es la mejor expresión de la debilidad racionalista

59 Si es un sistema singular y no generalizable, esto es, una facultad que unos disfrutan y otros no podrán hacerlo nunca, y ello sin ninguna razón que justifique ese diferente trato (salvo que la apelación a la Historia pueda ser considerada en el siglo xxI como una razón justificadora de una diferencia tan importante) desde una perspectiva jurídica es más correcto denominarlo "privilegio". Ahora bien, esta categoría sí que está expresamente prohibida por la Constitución que en su art. 138 establece que las diferencias entre Estatutos no podrán implicar privilegios.

60 Ante el protagonismo alcanzado por los derechos históricos en los debates de elaboración de los nuevos Estatutos de Cataluña y Valencia, Saiz Arnaiz reconoce que "poco puede extrañar semejante intento si se repara en el hecho de que a día de hoy, el único límite constitucional a la homogeneidad entre CCAA es precisamente la DAP». SAIZ ARNAIZ, A.: La titularidad de los derechos históricos...ob.cit. pág. 89. 
frente al historicismo" ${ }^{61}$. Veamos someramente como el historicismo ha sido reforzado en los nuevos Estatutos con cláusulas de dudoso encaje constitucional y finalidad claramente antidemocrática. Y ello porque aunque el historicismo puede tener muy distintos significados, como bien advirtió el profesor Francesc de Carreras durante la fase de elaboración del nuevo Estatuto catalán: "El historicismo considerado como el fundamento de instituciones políticas únicamente ha sido utilizado con una finalidad: eliminar, frenar o limitar la voluntad popular, el poder del pueblo, la capacidad de decisión de los ciudadanos. En definitiva, para impedir el ejercicio de los derechos democráticos ${ }^{62}$.

\subsection{Cataluña.}

La apelación a los derechos históricos para incrementar los poderes de la Comunidad Autónoma de Cataluña se planteó por vez primera en el seno de la Comisión de Estudio para la profundización del autogobierno que funcionó durante la VI Legislatura del Parlamento. En el documento finalmente aprobado, con la única excepción del Partido Popular, todas las fuerzas políticas presentes en la Comisión, se pronunciaron a favor de esta vía ${ }^{63}$. Posteriormente, el Informe sobre la Reforma del Estatuto justificó «la posible actualización de los derechos históricos en el caso de Cataluña" y ello porque la aplicación de la DAP a Cataluña abría "unas expectativas importantes para la reforma estatutaria" ${ }^{64}$. Cataluña había descubierto la DAP.

Cuando en enero de 2004 se constituye en el Parlamento de Cataluña una Ponencia, integrada por los distintos grupos, para elaborar la propuesta de reforma del Estatuto, también con la única excepción del Partido Popular, todos apoyaron la incorporación a aquel de los derechos históricos. No es este el lugar para examinar el iter legislativo del nuevo Estatuto. Baste subrayar que la LO 6/2006, de 19 de julio de reforma del Estatuto de Autonomía de Cataluña, contiene dos importantes alusiones a los derechos históricos (Preámbulo y ar-

61 Tudela Aranda, J.: “La Disposición Adicional Primera y los nuevos Estatutos de Autonomía ...ob.cit., pág. 166.

62 CARRERAs, De F.: "Reflexiones sobre la propuesta de nuevo Estatuto de Cataluña" en Teoría y Realidad Constitucional, núm. 16, 2005, pág. 64. En este sentido, la defensa de los derechos históricos por parte de las fuerzas políticas de izquierda es uno de los fenómenos políticos más asombrosos de los últimos años. Conviene recordar que el joven Marx fue uno de los más lúcidos opositores del historicismo, al que describió con estas acertadas palabras: «Una escuela que legitima la abyección de hoy por medio de la abyección de ayer, una escuela que declara como rebelión todo grito del siervo contra el látigo solo porque el látigo es antiguo, heredado, histórico...". Las fuerzas políticas (autocalificadas) de izquierda se sitúan en la senda de los principales representantes del pensamiento conservador y reaccionario, como pueden ser Burke o De Maestre.

63 Boletín Oficial del Parlamento de Cataluña, núm. 365, 5 de diciembre de 2002.

64 El Informe se elaboró por el Institut d'Estudis Autonomics con la colaboración de los profesores E. Albertí, E. Argullol, J. Vernet y C. Viver. IEA, Barcelona, 2003. 
tículo 5). Alusiones que debieron ser depuradas por las Cortes y, en su defecto, debiera depurar el Tribunal Constitucional.

El Preámbulo del nuevo Estatuto coloca en pie de igualdad a la Constitución y a los derechos históricos del pueblo catalán, como fundamento de un autogobierno "singular": "El autogobierno de Cataluña se fundamenta en la Constitución, así como en los derechos históricos del pueblo catalán que, en el marco de aquella, dan origen a este Estatuto al reconocimiento de una posición singular de la Generalidad". Fácilmente se ve aquí, una vez más, la apelación a la historia para justificar la diferencia ${ }^{65}$.

El historicismo del Preámbulo se proyecta sobre todo el articulado, pero de forma especial, encuentra su plasmación en el - a mi juicio, inconstitucional- artículo 5: "El autogobierno de Cataluña se fundamenta también en los derechos bistóricos del pueblo catalán, en sus instituciones seculares y en la tradición jurídica catalana, que el presente Estatuto incorpora y actualiza al amparo del artículo 2, la disposición transitoria segunda y otros preceptos de la Constitución, de los que deriva el reconocimiento de una posición singular de la Generalitat en relación con el derecho civil, la lengua, la cultura, la proyección de éstas en el ámbito educativo, y el sistema institucional en que se organiza la Generalitat".

Este importante precepto es susceptible de dos lecturas. Una estricta, en virtud de la cual la singularidad catalana se circunscribe a un régimen especial respecto a las concretas materias en él referidas. Y otra más amplia, que como apunta Tudela Aranda "vincularía la posición especial en esas materias con los preceptos constitucionales, mientras que los derechos históricos podrían servir para un juego más amplio, fundamentador de un futuro y más ambicioso régimen de autogobierno" ${ }^{66}$. En nuestra opinión, la finalidad del precepto se corresponde con esta segunda interpretación y ello porque para la primera, la referencia a los derechos históricos resulta por completo superflua. Cataluña puede asumir esas competencias sin necesidad de apelación alguna a hipotéticos derechos históricos.

En este sentido, el Consejo Consultivo de la Generalitat había advertido que las referencias a los derechos históricos pudieran ser inconstitucionales puesto que estos se identificaban con los territorios forales y que, en todo caso, no eran título competencial en materia de lengua o Derecho Civil, pues estas materias tenían ya títulos específicos. Estas acertadas advertencias no fueron atendidas por la clase política. Pero sobre todo, el Consejo en una de sus más acertadas observaciones sobre el proyecto estatutario afirmó que la inconstitucionalidad de dicha referencia reside en que "no puede existir una

65 En este Preámbulo, el legislador estatuyente insiste en el fundamento histórico del autogobierno al afirmar que "la libertad colectiva de Cataluña encuentra en las instituciones de la Generalitat el nexo con una historia de afirmación y respeto de los derechos fundamentales y de las libertades públicas de la persona y de los pueblos; historia que los hombres y mujeres quieren proseguir".

66 Tudela Aranda, J.: "La Disposición Adicional Primera y los nuevos Estatutos de Autonomía...ob. cit., pág. 169-170. 
doble legitimidad o una legitimidad alternativa al principio democráticon, es decir, una basada en el principio democrático y otra de fundamento histórico. Me parece importante subrayarlo porque es mérito del Consejo Consultivo haberse hecho eco con meridiana claridad de las tesis de García Pelayo que en este trabajo se defienden: la incompatibilidad entre la legitimidad histórica y la legitimidad democrática y la consecuente imposibilidad jurídica de admitir el principio de doble legitimidad ${ }^{67}$.

En definitiva, no se trata sólo de que los derechos históricos sólo pueden ser predicados respecto de los territorios forales, por lo que cualquier reconocimiento de derechos históricos a sujetos distintos de las Provincias Vascas y Navarra es inconstitucional, sino de que la fundamentación de la autonomía catalana en un título distinto a la Constitución democrática es incompatible con esta ${ }^{68}$.

La lectura conjunta del Preámbulo, y del artículo quinto del Estatuto de Cataluña pone claramente de manifiesto que en él se recoge el principio de doble legitimidad de la autonomía de Cataluña. Por esta razón, todas esas disposiciones son inconstitucionales. Frente a ello no cabe objetar (como se ha convertido en lugar común en los debates sobre numerosos aspectos de las reformas estatutarias) que son disposiciones neutras, esto es, que carecen de consecuencias o efectos concretos y que por lo tanto no incurren en vicio de inconstitucionalidad alguna. Resulta muy ingenuo creer que si el reconocimiento de esos supuestos "derechos históricos" carece de efectos se haya batallado tanto por ellos. Como hemos expuesto anteriormente tampoco nadie imaginaba que la DAP de la Constitución pudiera dar tanto juego. El artículo 5 se ubica en el conjunto de un nuevo Estatuto que, como ha advertido Muñoz Machado, reviste pretensiones cuasiconstitucionales, y en ese contexto, los derechos históricos distan mucho de poder concebirse como una categoría neutra. En este sentido, Saiz Arnaiz defiende la constitucionalidad de la fórmula catalana en la medida en que en ningún momento hace referencia a la DAP ${ }^{69}$. Sin embargo, esto lejos de solucionar el problema lo agrava. Si el Es-

67 En la meritoria - pero claramente insuficiente- labor depuradora del texto llevada a cabo por el Congreso de los Diputados, se suprimió la D.A del proyecto que reproducía la cláusula de no renuncia de los Estatutos vasco y navarro. Dicha supresión tiene escasa relevancia en la medida en que se mantiene la redacción del artículo 5. Sobre la incompatibilidad del artículo 5 del Estatuto con el artículo 1 de la Constitución, CARRERAs, De F.: "Reflexiones sobre la propuesta de nuevo Estatuto de Cataluña" en Teoria y Realidad Constitucional...ob. cit., págs. 63 y 64. Redactado cuando el proyecto legal estaba tramitándose, este estudio de F. de Carreras es uno de los más acertados análisis de los graves problemas de constitucionalidad que el texto planteaba y plantea.

68 En contra de esta tesis, defiende la constitucionalidad de las referencias a los derechos históricos, SAIz ARnaIz, A.: "Apreciar en esa apelación 'la pretensión de que exista un residuo de soberanía en Cataluña' tiene un indudable punto de exageración (...) «Recurrir a la historia para explicar, para justificar la propia autonomía, no tendría porque resultar sospechoso". A esto cabe objetar que, efectivamente, la historia puede servir para explicar cualquier cosa, lo que no puede es ser utilizada como título legitimador. SAIZ ARNAIZ, A.: "La titularidad de los derechos históricos y las reformas...ob.cit. pág. 127.

69 SaIz Arnaiz, A.: "La titularidad de los derechos históricos y las reformas...ob.cit., pág. 128. 
tatuto catalán no se refiere a los derechos históricos de la DAP (porque están reservados a las Provincias Vascas y a Navarra) ¿a qué derechos históricos se está refiriendo?, ¿cuál es su contenido?, y sobre todo, ¿qué finalidad persiguen?

En todo caso, a pesar de defender la constitucionalidad del artículo 5 del nuevo Estatuto y de la apelación a los derechos históricos (precisamente por no referirse expresamente a la DAP, que como el propio autor bien argumenta no es de aplicación a Cataluña), el profesor Saiz Arnaiz reconoce que "la polémica de los derechos históricos en el nuevo Estatuto de Cataluña no puede darse, ni mucho menos, por concluida" y ello no sólo porque todo está pendiente de lo que resuelva el Tribunal Constitucional, sino también por la "VOluntad de algunas fuerzas políticas, de explotar todas las posibilidades que ofrece el Estatuto reformado". Desde esa perspectiva, el inconstitucional reconocimiento de unos derechos históricos y de una posición singular de Cataluña, abre la puerta a una indefinida espiral reivindicativa. Baste, a título de ejemplo, recordar unas declaraciones de uno de los "padres" del nuevo Estatuto, el dirigente de CIU F. Homs. El político catalán defendía con entusiasmo las "potencialidades jurídicas" del Estatuto, y entre ellas ocupaba un lugar destacado el reconocimiento de los derechos históricos de Cataluña: "los derechos históricos sirven para ampliar competencias, porque son los que de verdad dan contenido a la nacionalidad, al hecho diferencial, en términos constitucionales" ${ }^{70}$. Debo reconocer que esas "potencialidades" producen pavor a quienes defendemos la subsistencia del Estado Constitucional español como unidad de acción y decisión política. En todo caso, lo que no podemos hacer es interpretar el artículo 5 en contra de su propio tenor literal, en contra de su propio sentido, en contra del significado real de la apelación a la historia como título legitimador de la singularidad catalana, en contra de lo que entienden la mayoría de los diputados que en Cataluña lo respaldaron...para concluir que (como tantas veces se ha dicho) es un precepto sin consecuencias jurídicas y por ello no es contrario a la Constitución. Frente a ello hay que reconocer que el precepto incluye el inconstitucional principio de doble legitimidad, y que, se quiera o no, tendrá efectos. Por la incompatibilidad de dicho principio con el ordenamiento constitucional vigente, debe ser reputado inconstitucional.

Como acertadamente concluye Tudela Aranda, el examen del texto catalán pone de manifiesto dos cosas: "por un lado, la afirmación de una continuidad histórica del autogobierno de Cataluña que singulariza su ser en el conjunto del Estado y fundamenta, con la Constitución, su autonomía; por otro, la recepción en el articulado de unos derechos históricos del pueblo catalán, sean cuáles sean, como fuente de una posición singular de la Generalidad en relación con determinadas materias. De nuevo emerge la oscuridad denunciada por García Pelayo al hilo de la redacción de la DAP y con consecuencias previsiblemente similares a las que él temía ${ }^{71}$

70 La Vanguardia, 11 de setiembre de 2006.

71 Tudela Aranda, J.: "La Disposición Adicional Primera y los nuevos Estatutos de Autonomía...ob.cit., pág. 170 
En todo caso, y esto es algo que importa subrayar, el principal objetivo perseguido por los impulsores de la reforma estatutaria no se logró. Aunque el nuevo estatuto contiene nuevas disposiciones en materia de financiación, evidente resulta que no extiende a Cataluña el privilegiado sistema de financiación vasco-navarro. Desde esa perspectiva algunos pueden considerar el Estatuto como un fracaso. Sin embargo, también puede ser concebido como un paso adelante. Salvo que el Tribunal Constitucional anule los preceptos citados, a partir de ahora el bloque de constitucionalidad reconocerá la existencia de unos "derechos históricos" cuyo contenido real y alcance sólo el futuro (y no la historia) podrán determinar. En la medida en que este reconocimiento se produce en un contexto en el que se debaten abiertamente cuestiones como "el derecho de autodeterminación" o el recientemente inventado "derecho a decidir", constituiría un ejercicio de ingenuidad irresponsable pretender negar su trascendencia. La inclusión del principio de doble legitimidad en el nuevo Estatuto (además de ser jurídicamente inconstitucional), resulta políticamente inoportuna y peligrosa, desde la perspectiva del deseable mantenimiento de la unidad de nuestro Estado Constitucional.

\subsection{VALENCIA}

La lectura de la Proposición de reforma del Estatuto de Valencia elaborada por el PP y el PSOE en mayo de 2005, ponía claramente de manifiesto que también Valencia reclamaba su plena condición foral y la aplicación de la DAP ${ }^{72}$. El Congreso de los Diputados cortó de raíz tales pretensiones ${ }^{73}$. Todas las referencias al Derecho Foral Valenciano se transformaron en Derecho "Civil" Foral Valenciano y la mención a la DAP fue suprimida. En definitiva, las Cortes Generales borraron todo rastro de foralidad de Derecho Público ${ }^{74}$.

A pesar de ello, el carácter historicista del nuevo Estatuto Valenciano llega a revestir, en ocasiones, dimensiones ridículas. El hecho de ser el primer Estatuto pactado por las principales fuerzas políticas (PSOE y PP) no le ha librado, desafortunadamente, de ese tipo de excesos. Juzgue el lector el tenor del artículo 57: "El Real Monasterio de Santa María de la Valldigna es templo espiritual, político, histórico y cultural del Antiguo Reino de Valencia, hoy Comunitat Valenciana, y es igualmente, símbolo de la grandeza del Pueblo Valenciano reconocido como Nacionalidad histórica. Una ley de Les Corts determinará el destino y la utilización del Real Monasterio de Santa María de Valldigna como punto de encuentro y unión sentimental de todos los valencianos y como centro de investigación y estudio para recuperar la historia de

72 La referencia era expresa en la Disposición Transitoria Tercera de la Propuesta.

73 ERC, la gran defensora del historicismo en los debates estatutarios, propuso sin éxito una enmienda según la cual "el autogobierno del País Valenciano se fundamenta en los derechos históricos del pueblo valenciano, que este Estatuto incorpora y actualiza”. (BOCD, serie B, núm. 1967, de 16 de noviembre de 2005, enmienda núm. 59).

74 SaIz ArnaIz, A.: "La titularidad de los derechos históricos y las reformas...ob.cit. pág. 131. 
la Comunitat Valenciana”. Aprobado por unanimidad. Y señalo esto para denunciar que constituye un impresionante ejercicio de falsificación de la realidad pretender imputar al PSOE, en exclusiva, la responsabilidad del nuevo modelo de organización territorial surgido de los nuevos Estatutos aprobados durante la VIII Legislatura. Salvo el de Cataluña, que fue aprobado con los votos en contra del Partido Popular, todos los demás fueron aprobados prácticamente por unanimidad y con el apoyo entusiasta de socialistas y populares. En definitiva, y esto es lo que importa subrayar en orden a nuestro tema, el discurso historicista y la retórica particularista e identitaria no son patrimonio exclusivo de las fuerzas políticas regionalistas, nacionalistas o secesionistas, sino que forma parte del acervo ideológico y de los proyectos políticos de los dos grandes partidos nacionales. Razón esta que, inexcusablemente, conduce al escepticismo sobre el futuro del Estado constitucional español como Estado unitario.

La retórica identitaria e historicista que recoge el Preámbulo se proyecta sobre los artículos primero y séptimo del Estatuto: El artículo primero dispone: «El pueblo valenciano, históricamente organizado como Reino de Valencia, se constituye en Comunidad Autónoma, dentro de la unidad de la Nación española, como expresión de su identidad diferenciada como nacionalidad bistórica y en el ejercicio del derecho de autogobierno que la Constitución reconoce a toda nacionalidad, con la denominación de Comunitat Valenciana". Por su parte, el artículo séptimo del estatuto contiene una referencia expresa a los Fueros del Reino de Valencia: «El desarrollo legislativo de las competencias de la Generalitat procurará la recuperación de los contenidos correspondientes de los Fueros del Antiguo Reino de Valencia en plena armonía con la Constitución y con las exigencias de la realidad económica y social valenciana".

Dejemos a un lado las dificultades existentes para compatibilizar los Fueros del antiguo Reino de Valencia con la Constitución y la realidad socioeconómica del siglo xxi. Lo que importa subrayar es que en el nuevo Estatuto valenciano, la apelación a la Historia del artículo primero sirve de cobertura en el artículo séptimo a la pretensión de recuperar un indefinido e impreciso acervo competencial (identificado con los antiguos Fueros) al margen del reparto competencial constitucionalmente establecido ${ }^{75}$. Como advierte Saiz Arnaiz nadie ha sostenido - y no lo haré yo- que el artículo 7 sea inconstitucional. La diferencia fundamental con el texto catalán es que no hay reconocimiento de derechos históricos ni de posición singular alguna. Ahora bien, no resulta del todo claro que la referencia a los Fueros de Valencia carezca por completo de valor normativo.

75 Tudela Aranda, J.: «La Disposición Adicional Primera y los nuevos Estatutos de Autonomía...ob.cit., pág. 171. 


\subsection{Andalucía, Islas Baleares y Aragón.}

En este somero repaso habría que mencionar también la fuerte carga historicista de los Estatutos andaluz y balear. En ambos casos ello tiene su reflejo principalmente en los textos preambulares. El Preámbulo del nuevo Estatuto de Andalucía es ante todo una proclamación de las raíces históricas de Andalucía que fundamenta su consideración como un sujeto político con identidad y cultura diferenciadas: "Andalucía, a lo largo de su historia, ha forjado una robusta y sólida identidad que le confiere un carácter singular como pueblo, asentado desde épocas milenarias (...) El ingente esfuerzo y sacrificio de innumerables generaciones de andaluces y andaluzas a lo largo de los tiempos se ha visto recompensado en la reciente etapa democrática que es cuando Andalucía expresa con más firmeza su identidad como pueblo a través de la lucha por la autonomía plena”. En todo caso, no hay aquí referencia alguna a los derechos históricos. Sí a la historia (milenaria, por supuesto), como fundamento no sólo de la autonomía, sino también de la imprescindible singularidad. El historicismo que llega a defender en el Preámbulo del Estatuto el carácter de "realidad nacional" de Andalucía se proyecta en el articulado en su definición como "nacionalidad histórica". Como si la voluntad ciudadana no fuera mejor título fundamentador del autogobierno que cualquier rancia referencia al pasado, el estatuyente andaluz apela también a su historia.

La lectura del Preámbulo del Estatuto balear contiene también un relato mágico sobre el idílico pasado del archipiélago. Esa Historia mítica es el presupuesto de una identidad colectiva y explica que la nacionalidad histórica de las Islas Baleares rinda "homenaje a todos sus hijos que a lo largo de los tiempos, lejanos y próximos, han trabajado para mantener la identidad de nuestro pueblo". Tampoco en el articulado hay referencias a los derechos históricos, pero el principio identitario se proyecta sobre todo el texto.

Hemos dejado para el final, el examen del texto aragonés. Como ya hemos señalado, el Estatuto aragonés era el único que, junto con el vasco y el navarro, contenía una referencia expresa a los derechos históricos. Sin embargo, la virtualidad de esa referencia ha sido escasa por no decir nula. Resulta significativo que en un Dictamen sobre profundización del autogobierno aprobado por unanimidad por los cinco Grupos parlamentarios de las Cortes de Aragón, la única mención a los derechos históricos tuviera por objeto vincularlos a la concreción de un modelo singular de financiación. Se recuerda expresamente en el citado Dictamen que las dos Comunidades cuyos Estatutos recogen los derechos históricos poseen sistemas singulares de financiación ${ }^{76}$. Pero lo cierto es que en la elaboración del nuevo estatuto esta cuestión no ha suscitado interés. Aunque se trata de un texto que, como todos, pone la vista en el pasado y alude a la historia como creadora de una identidad diferenciada, hay que reconocer que, a lo largo del proceso de elaboración, ex-

76 Debates parlamentarios sobre la profundización y desarrollo del autogobierno aragonés, Cortes de Aragón, Zaragoza, 2004. 
perimentó una depuración de sus mayores excesos historicistas. A título de ejemplo baste señalar que una disposición del proyecto preambular establecía que el autogobierno de Aragón se fundamenta en la Constitución "así como en los derechos históricos del pueblo aragonés, que en el marco de aquella, dan origen en este Estatuto al reconocimiento de una posición singular de nuestra Comunidad Autónoma". Aquí, —a diferencia de lo ocurrido en Cataluña y de forma similar a lo acaecido en Valencia- la sensatez se impuso, y dicha alusión (inconstitucional) fue suprimida del texto definitivo.

\subsection{Conclusiones.}

Recapitulando sobre lo expuesto nos encontramos con que Valencia, Andalucía, Aragón y Baleares se han definido como nacionalidades históricas. En todos los Estatutos, de una u otra suerte, se apela a la Historia como fundamento de la autonomía y de la diferencia. Como bien advierte Tudela Aranda, "la historia ha sido percibida como rentable y necesaria, convirtiéndose en elemento de referencia en el nuevo debate estatutario. Desde esta perspectiva, no puede extrañar que las apelaciones a la historia se extiendan progresivamente. Si a la historia se acude como primer factor legitimador de la diferencia, sino del privilegio, es normal que cada cual busque en el baúl familiar las referencias necesarias para, al menos, lograr la equiparación" ${ }^{77}$.

Todo esto sólo puede ser entendido como una reacción de las denominadas comunidades de régimen común frente a las comunidades forales. Desde esta perspectiva, la ofensiva historicista traería causa de la propia DAP de la Constitución. El discurso historicista, en otro contexto, resultaría difícilmente explicable. Ahora bien, lo que no podemos olvidar es que cuando se apela a la historia se deja de apelar al pueblo real (los ciudadanos del presente) en beneficio de un pueblo histórico, milenario pero mítico. Cuando la autonomía se fundamenta en el pasado, se desvaloriza la voluntad de los ciudadanos del presente. Y lo que es más grave, se pretende, de una u otra suerte, establecer una distinción entre diferentes autonomías en función de su respectivo pasado histórico. Esta pretensión resulta incompatible con el sistema de valores del Estado constitucional vertebrado en torno a la igual libertad y a la justicia. En la medida en que todos los ciudadanos de España son iguales, las respectivas Comunidades Autónomas que no tienen ni pueden tener otro fundamento que la voluntad de esos ciudadanos, han de ser también —si dichos ciudadanos así lo quieren (y nadie va a querer ser menos que otro) iguales. Y afirmo esto, con rotundidad, porque uno de los datos más significativos del debate territorial es el desprecio indisimulado con que, tanto en sede política como académica, los más ilustres portavoces de nuestro historicismo contemplan el deseo de autogobierno de aquellas Comunidades que

77 Tudela Aranda, J.: "La Disposición Adicional Primera y los nuevos Estatutos de Autonomía...ob.cit., pág. 175. 
no presumen de su pasado. Como si la voluntad de sus habitantes, si así lo expresasen, no fuese motivo suficiente.

En definitiva, la extensión del principio de legitimidad histórica ha supuesto la correlativa reducción del principio de legitimidad democrática del Estado Autonómico. Lo que al amparo de la DAP se ha pretendido ignorar es que la Constitución no tiene otro fundamento que la voluntad soberana del Pueblo español, y que, igualmente, el principio de autonomía política se basa exclusivamente en esa voluntad. Con esas premisas, el autogobierno de cada una de las 17 Comunidades Autónomas creadas por los distintos estatuyentes no tiene ni puede tener en un sistema democrático otra legitimidad o fundamento que la voluntad de los ciudadanos de las provincias que las componen. El País Vasco, Navarra o Cataluña no necesitan, en modo alguno, apelar a la Historia para fundamentar un autogobierno que les reconoce la Constitución en su artículo 2. Si lo hacen, no es por tanto, para justificar un autogobierno constitucionalmente reconocido, sino para legitimar a perpetuidad diferencias y singularidades respecto a otras comunidades. El no disimulado propósito del derecho histórico no es otro que legitimar la diferencia, esto es transformar lo que realmente es un privilegio en un "hecho diferencial". Desde esta perspectiva, los derechos históricos son incompatibles con el principio federal.

Los derechos históricos mencionados en la DAP de la Constitución han reportado sustanciosos beneficios a sus titulares. Por ello se ha producido un efecto de contagio. Ahora todos quieren fundamentar su autonomía en la Historia. En este sentido, el proceso de reformas estatutarias de la VIII Legislatura ha supuesto un salto cualitativo de importancia. La DA Primera de la Constitución ha experimentado una mutación notable. Como advierte Tudela Aranda "Sólo de verdadera mutación genética puede calificarse la forma en que aparecen en el Estatuto de Autonomía de Cataluña o en el Texto valenciano. Habiendo saltado su barrera primitiva de especie, sólo resta saber si se trata de un caso aislado o de pandemia generalizada. La pregunta crucial es si van a limitar sus efectos a la literalidad de los textos estatutarios o si, por el contrario, van a servir, como ha sucedido con la DAP y sus correlativas disposiciones estatutarias, para legitimar dosis de autogobierno "estraestatutarias" ${ }^{78}$.

78 Tudela Aranda, J.: «La Disposición Adicional Primera y los nuevos Estatutos de Autonomía ...ob.cit., pág. 176. "Todo ello ha tenido también como consecuencia mantener el debate en unos umbrales de transparencia muy alejados de lo exigible en una democracia, máxime cuando las cuestiones que se debaten son de la mayor importancia para todos. Siempre queda por preguntarse sobre el porqué de esta abundancia de historicismo y retórica mítica, el porqué de la incapacidad de hacer descender el debate al nivel de la racionalidad y la decisión democrática. Puede entenderse desde la instrumentalizad política, en el nacionalismo. Pero no puede entenderse en el resto. Quizá el problema sea la propia debilidad de nuestra historia política, debilidad que no puede dejar de ser terreno abonado para esa retórica maximalista", pág. 178. Como expuse al inicio de este trabajo, esa debilidad congénita de nuestro constitucionalismo tiene su origen en el contexto en que se gesta la Constitución gaditana. 
Pocas dudas albergo de que los derechos históricos serán utilizados (o intentarán serlo, al menos) para esto último, en definitiva para sustituir el Estado Constitucional vigente por una confederación de Estados. Obligado es recordar de nuevo la advertencia del maestro García Pelayo: "Esta ambigüedad básica es el comienzo de muchas más, abre paso a interpretaciones teóricas y prácticas de gravedad incalculable y, sobre todo, proporciona un arsenal de argumentos jurídicos que pueden ser esgrimidos, sea articulados en estrategias políticas audaces y de largo alcance, sea para finalidades más modestas — por ejemplo, destinadas a crear un ámbito privilegiado en materia fiscal o en otro campo- pero no por eso menos perturbadoras del sistema político y la vigencia del orden constitucional" ${ }^{79}$.

Lo cierto es que aunque el proceso de reformas estatutarias en clave historicista no ha servido para expandir privilegios fiscales a las quince comunidades de régimen común (la generalización del sistema de financiación foral conduciría a la quiebra del Estado), lo que sí ha permitido es la expansión del paradigma foral, esto es del pactismo. En todos los nuevos Estatutos se establece el principio de relación bilateral entre la Administración de la Comunidad y la central. Y es que, aunque pueda sorprender a quienes consideran nuestro sistema de organización territorial un paradigma de progreso y de modernidad, el gran hispanista J. Elliot ha advertido, con gran agudeza, que lo que más sorprende al historiador es el parecido de la España Autonómica a la España de los Austrias ${ }^{80}$.

El profesor Laporta también se ha expresado en términos muy críticos con esta deriva historicista de los nuevos Estatutos: "Mientras la Constitución se mantiene en el terreno de la teoría racional-normativa del derecho a la hora de interpretar la noción de derechos históricos, los diferentes estatutos se han pasado con armas y bagajes a la visión historicista. Es hora ya, por tanto, de cuestionarse si eso no supone un quebrantamiento de la Constitución" ${ }^{81}$. Comparto su conclusión aun cuando discrepe de la premisa. La deriva historicista ha sido posible porque los derechos históricos no son susceptibles de una interpretación basada en la teoría racional-normativa de la Constitución.

Por su parte, el profesor Saiz Arnaiz, con un optimismo que lamento no poder compartir, ha hablado de "fin de trayecto": "Se ha establecido una suerte de convención para impedir la extensión de la asimetría que resulta natu-

79 Garcia Pelayo, M.: Obras completas...ob.cit. Pág. 3175. En el mismo sentido, el profesor Sosa Wagner denuncia como: "La siembra - que ha resultado fecunda de tal pensamiento en los huertos de otros nacionalismos hispanos pone de manifiesto lo arraigado de ese deseo de singularidad, de exención o de inmunidad, de acuerdo o pacto, que ahora se llama 'bilateralidad'. Los frutos obtenidos se trasladarán a las demás CC. AA., porqué ¿quién va a negar derechos históricos a astures, cántabros, castellanos, andaluces, toledanos, mallorquines, leoneses, etc.? Todo ello es incompatible con el Estado moderno y muy especialmente con el Estado federal". SosA WAGner, F.: El Estado fragmentado, Trotta, Madrid, 2007.págs. 149-150.

80 Elliot, J.: "Constitucionalismo antiguo y moderno" en Cuadernos de Alzate, núm. 33, 2005, págs. 7 y ss.

81 Laporta, F.J. «Los derechos históricos en la Constitución...ob.cit, págs. 34-35. 
ralmente de la aplicación de la DAP fuera del espacio vasco-navarro (...) La exclusión lo ha sido al precio de incorporar a los textos reformados unas imprecisas referencias a los Fueros, a la normativa foral o a los derechos históricos que, sin duda, se prestan a la controversia, pero que en ningún caso se acompañan de remisiones a la DAP” ${ }^{82}$. ¿Hasta cuándo podrá durar esa supuesta convención impuesta por el PP y el PSOE? El PSC demanda —en el momento de redactar estas líneas (y no cesará en ese legítimo empeño) — al PSOE un sistema de financiación que le reporte un resultado similar al foral. Ahora pueden solicitarlo al amparo de los derechos históricos que según el artículo 5 del nuevo Estatuto fundamenta la autonomía catalana. El rechazo de estas pretensiones en virtud de la mencionada convención se basa en una construcción jurídica que no creo que pueda — ni deba- mantenerse por mucho tiempo. Existen diferentes tipos de "derechos históricos": los de la DAP que tienen rango constitucional y amparan privilegios fiscales y los del Estatuto catalán que aun integrados en el bloque de la constitucionalidad (salvo que fueran anulados por el Tribunal Constitucional), son de distinta naturaleza que los de la DAP y no proporcionan cobertura para un sistema de financiación singular. Esa radical desigualdad tiene un fundamento constitucional y la convención de la que habla el profesor Saiz Arnaiz pretende consagrarla indefinidimante. En términos políticos creo que los partidos políticos de ámbito nacional no podrán, por mucho tiempo, soportar las tensiones derivadas de esa desigualdad. En términos jurídicos, como expondré en el siguiente apartado, considero que esa desigualdad, y su fundamento, esto es la DAP, resulta contraria a nuestra Constitución. Y en términos éticos, esto es desde una perspectiva axiológica centrada en los valores de igualdad, justicia y solidaridad, la desigualdad de regímenes jurídicos establecida al amparo de la DAP en la medida en que afecta a la igual libertad de las personas y a sus condiciones de vida, tampoco resulta admisible.

Llegados a este punto y a la vista de lo anterior creo que resulta inexcusable plantearse el estudio de los derechos históricos desde la necesaria dia-

82 En este sentido ha escrito lo siguiente: "A estas alturas ha de evitarse toda lectura exagerada (en una u otra dirección) de la DAP, y ello es posible porque existe una communis opinio suficientemente decantada sobre los titulares de los derechos históricos, sobre los límites constitucionales de su respeto y amparo y sobre las posibles consecuencias de su actualización estatutaria". SAIZ ARNAIZ, A.: "La titularidad de los derechos históricos y las reformas...ob.cit., págs. 132133. Frente a tan optimista conclusión creo que ni siquiera en sede académica la cuestión resulte tan pacífica: el significado y alcance de la DAP es susceptible de muy diferentes interpretaciones. Pero sobre todo, el debate político pone de manifiesto que la categoría de los derechos históricos se configura como un instrumento de "potencialidades" cuasilimitadas. La interpretación jurídica no puede prescindir del contexto de la realidad social y política, y en ese contexto, la apelación a los derechos históricos es - y seguirá siendo- expresión tanto de un conflicto de legitimidades, como de una sensación de agravio comparativo. De hecho el autor citado concluye su meritorio y sugerente ensayo advirtiendo que la DAP "quizá próximamente, podrá seguir provocando sus excepcionales efectos" con lo que viene a contradecir su conclusión sobre "el fin de trayecto" de la DAP (salvo que ese fin se refiera sólo a los titulares de los derechos históricos y no a su contenido). 
CONSTITUCIÓN Y DERECHOS HISTÓRICOS: LEGITIMIDAD DEMOCRÁTICA FRENTE A LEGITIMIDAD... 173

léctica legitimidad democrática o racional frente a legitimidad histórica. La problemática de los derechos históricos, como subraya el que fuera portavoz de los Senadores Vascos en la Constituyente, Mitxel Unzueta, "es una cuestión de legitimidad y no una disputa sobre competencias como con tanta frecuencia se insiste". Y desde la perspectiva de la legitimidad, como venimos apuntando, debemos afirmar que, a pesar de su recepción por el constituyente de 1978, los derechos históricos son una categoría incompatible con el orden material de valores de la Constitución democrática. Por decirlo con mayor claridad, la DAP por recoger esa categoría es una disposición inconstitucional.

\section{LAS DENOMINADAS «NORMAS CONSTITUCIONALES INCONSTITUCIONALES": LA INCONSTITUCIONALIDAD DE LA DISPOSICIÓN ADICIONAL PRIMERA.}

Admitir que el particular sistema de financiación del País Vasco y de Navarra es un privilegio inconstitucional, y defender que la categoría misma de derechos históricos, en la que aquel pretende encontrar cobertura, es incompatible con la Constitución, supone reconocer que un precepto constitucional es contrario a la Constitución. Esto implica aceptar una tesis que la doctrina española rechaza mayoritariamente: la existencia de normas constitucionales inconstitucionales ${ }^{83}$.

Sin embargo, creo que se trata de una categoría cuya existencia no puede ser negada. Desde esta perspectiva, y de la misma forma que ocurre con cualquier norma jurídica infraconstitucional, podemos hablar de inconstitucionalidad formal y material. Por lo que se refiere a la primera, dado que nuestra Constitución prevé dos procedimientos distintos para la reforma constitucional en función de los artículos que se quieran modificar, debemos admitir que reformar un precepto protegido por el procedimiento de reforma del artículo 168 (por ejemplo la sucesión a la Corona) mediante el artículo 167, daría lugar a una norma constitucional viciada de inconstitucionalidad formal. Aunque nada hubiera que objetar a su contenido, en la medida en que la norma no ha sido aprobada por el procedimiento constitucionalmente correcto, incurre en inconstitucionalidad. En este sentido hay que admitir que

83 Sobre las normas constitucionales inconstitucionales, BACHOF, O.: Normas constitucionais inconstitucionais?, (1951) traducido del alemán al portugués por J.M. Cardoso da Costa. Almedina, Coimbra, 1994. Véase también la nota previa del traductor (en la actualidad Presidente Emérito del Tribunal Constitucional de Portugal) y su defensa de esta categoría. "Planta exótica en nuestro jardín constitucional" ha sido considerada por Fernando Rey en su sugerente crítica a la misma, pero realizada frente a un supuesto que no encaja en ella, la preferencia del varón en la sucesión a la Corona. Rey, F.: "Derecho de sucesión en la Corona y discriminación por razón de sexo: análisis de la posible supresión de la preferencia sucesoria de los varones" en El Informe del Consejo de Estado sobre la reforma constitucional. Texto del informe y debates académicos. Consejo de Estado-CEPC, Madrid, 2006, pág. 423. 
incluso algunos de los que rechazan la doctrina de las «normas constitucionales inconstitucionales" reconocen el carácter problemático de este tipo de supuestos. En nuestra opinión, y aunque pudiera considerarse que el supuesto no está regulado y que nos encontramos con una laguna, en estos casos corresponde, sin duda alguna, al Tribunal Constitucional, anular la reforma. El cauce para ello no podría ser otro que el del recurso de inconstitucionalidad, aunque convendría establecer un sistema específico de control de constitucionalidad de las reformas, y preferentemente de carácter previo. Sea de ello lo que fuere, el análisis en profundidad de esta problemática desborda el objeto de nuestro estudio. A nuestros efectos, baste con retener que una norma de la constitución podría ser reputada inconstitucional en el caso de ser aprobada sin respetar el procedimiento constitucionalmente previsto (arts. 166-169 CE).

Más controvertido resulta admitir que una norma constitucional aprobada por el Poder constituyente originario o en su caso por el poder de reforma (arts. 166-168 CE) pueda ser considerada inconstitucional por razones materiales, y ello porque en ese caso el parámetro para efectuar ese juicio vendría configurado por otras normas sustantivas de la propia Constitución. Tal posibilidad es rechazada por la doctrina mayoritaria puesto que el principio de unidad e interpretación sistemática del texto constitucional exige reconocer a todas sus disposiciones un mismo rango sin que resulte admisible subordinar unas a otras en función del principio de jerarquía. Sin embargo, creo que esto es una proposición dogmática que contradice la realidad. En la misma existencia de dos procedimientos de reforma subyace la idea de una gradación (muy criticable en su concreta configuración positiva) de las normas constitucionales. Pero, además, resulta evidente que el valor del artículo 1 o 10 de la Constitución por poner dos ejemplos no puede ser idéntico al del artículo 5. Entre otras cosas porque el artículo 5 podría ser reformado o suprimido y determinadas disposiciones del artículo 1 o 10 no pueden ser objeto de revisión. Pero en todo caso el problema surge no por la coexistencia de normas constitucionales de distinto valor, sino de normas contradictorias o incompatibles. Cuando esto ocurre, - $-\mathrm{y}$ por lo que a nuestro tema interesa la incompatibilidad es manifiesta entre el artículo 1 y la DAP de la Constitución-, negar la existencia del problema puede parecer la solución más fácil, pero evidente resulta que por negarlo no queda resuelto.

La doctrina de las normas constitucionales inconstitucionales por razones materiales nos remite, necesariamente, al clásico y nunca definitivamente cerrado debate sobre la existencia de límites materiales implícitos al procedimiento de reforma constitucional ${ }^{84}$.

84 De hecho, la negación de esos límites sirve generalmente para rechazar la posibilidad misma de existencia de normas constitucionales inconstitucionales. Por todos, REY, F.: "Derecho de sucesión en la Corona y discriminación por razón de sexo: análisis de la posible supresión de la preferencia sucesoria de los varones" en El Informe del Consejo de Estado sobre la reforma constitucional. Texto del informe y debates académicos. Consejo de Estado-CEPC, Madrid, 2006, pág. 423. 


\subsection{Los límites materiales al Poder de Reforma Constitucional.}

En una brillante y sugerente conferencia pronunciada en Salamanca el 23 de mayo de 2002, en el marco de unas Jornadas organizadas por la Fundación Sistema, sobre "El desarrollo de la democracia" denunciaba Pedro De Vega el actual predominio de las concepciones instrumentales y formalistas de la democracia, caracterizadas por una lamentable y perniciosa subordinación de los contenidos (valores) a las formas (reglas del juego): "(...) adquieren de día en día mayor consistencia las concepciones instrumentales y formalistas de la democracia, en las que paradójicamente la política se queda sin escenarios reales, y los valores y principios democráticos se disuelven en un sistema de ficciones y alegorías" ${ }^{85}$. Concepciones instrumentales y formalistas que se caracterizan por el hecho "de que en lugar de partir, en sus elaboraciones teóricas, de los principios y valores que dieron grandeza política y moral a la democracia (libertad, igualdad, fraternidad), comienzan tomando como base de sus razonamientos los aparatos institucionales".

El profesor De Vega alude así a los patológicos efectos que genera la perniciosa escisión entre formas y contenidos, y que en última instancia acaba subordinando estos a aquellas ${ }^{86}$. La cita es larga, pero considero justificada su transcripción completa habida cuenta de que se trata de uno de los más autorizados y lúcidos testimonios de denuncia por parte de la doctrina constitucional española de la hoy tan en auge democracia procedimental: "La sacralización del aparato institucional como sistema de referencia en el que se expresan los equilibrios y las reglas del juego político, en detrimento de los valores y principios que constituyen su fuente de inspiración, tiene como traducción inmediata el hecho de que el respeto de esas reglas pasa a convertirse en criterio rector, presupuesto de legitimidad y dogma indiscutible para enjuiciar toda la vida política democrática. Lo que no tendría mayor significación ni importancia si no fuera porque la divinización de las formas y de las reglas del juego para lo único que ha servido, como puede comprobarse fácilmente, ha sido para raptar de la vida y de la historia los valores que dan sentido a la idea democrática" ${ }^{87}$.

85 De Vega, P.: "La democracia como proceso. (Algunas consideraciones desde el presente del republicanismo de Maquiavelo)" en Alternativas para el siglo XXI. Alfonso Guerra y José Félix Tezanos (eds.), Editorial Sistema, Madrid, 2003, pág.462.

86 Esta es la premisa básica de todos aquellos, incluido nuestro Tribunal Constitucional en su sentencia 48/2003, que afirman, hiperbólicamente, que en nuestro ordenamiento constitucional caben todas las ideologías y todos los fines (incluidos por tanto también los contrarios a los valores constitucionales) siempre que se defiendan por procedimientos democráticos o mediante formas democráticas. Equiparando a su vez de una forma inaceptablemente reduccionista democrático con no violento.

87 De VegA, P.: “La democracia como proceso... ob. cit., págs. 462-463. «Es difícil encontrar en la actualidad, entre los teóricos de la democracia y de la Constitución, textos en los que se denuncien los riesgos derivados de los intentos de reducir la democracia a un sistema de reglas del juego, y donde se critique el colosal disparate de pretender convertir las cuestiones de legitimidad en meras cuestiones de legalidad, sin una previa fundamentación democrática de la legalidad”, pág. 464. 
Las anteriores divergencias sobre la concepción de la democracia encuentran su proyección y reflejos inmediatos en diferentes formas de entender el instituto de la Reforma Constitucional. Nada de extraño tiene que, en un contexto en el que un amplio sector doctrinal parece optar, como denuncia Pedro de Vega, por la democracia procedimental, para muchos, hablar de la existencia de límites materiales implícitos al poder de reforma, en el marco de un ordenamiento constitucional que como el nuestro prevé en su artículo 168 la revisión total del Texto Fundamental, pueda parecer un colosal despropósito. Y sin embargo, lejos de serlo, y como nos lo ha advertido con acierto la mejor doctrina (Mortati, Hesse, Pérez Serrano, Lucas Verdu, De Vega, Ruipérez) es la única opción válida desde el punto de vista de la lógica jurídica y política que está insita en el proceso de formación y consolidación del Estado Constitucional. Dicho con otras palabras, el Estado Constitucional reposa sobre la distinción entre poder constituyente y poderes constituidos y no se puede hablar de Constitución normativa si admitimos que el poder de reforma, que se configura necesariamente como un poder constituido, puede actuar sin más límites que los procedimentales.

La idea misma de Constitución normativa nos obliga a configurar al Poder de reforma como un poder limitado no sólo procedimentalmente sino también materialmente. Y ello con independencia de que dichos límites hayan sido expresamente dispuestos por el constituyente en las denominadas cláusulas de intangibilidad. Como ha escrito Pedro de Vega en una obra ya clásica, y difícilmente superable, sobre este tema: "Si el principio jurídico de supremacía constitucional impone el reconocimiento de unos límites implícitos formales que se centran, básicamente, en las propias normas reguladoras del procedimiento de reforma, el principio político de soberanía popular condicionará, por su parte, la obligada aparición de unos límites implícitos materiales, cuya fundamentación y desarrollo han de ser deducidos, desde la lógica de la legitimidad, como necesario correlato de los valores materiales y los supuestos políticos en que se inspira y se vertebra el moderno Estado constitucional" 88 .

En este sentido, no merece la pena discutir sobre si los principios y los valores legitimadores del ordenamiento constitucional forman parte o no de la realidad jurídica y tienen, por tanto, un valor normativo o no, en la medida en que, con frecuencia, y así ha ocurrido en el caso español, dichos principios y valores han sido expresamente recogidos por el constituyente (artículos 1 y 10). Por ello, lo que importa es subrayar que «lo que resulta incuestionable es que, bien cuando aparecen como elementos claramente definidos en los textos constitucionales o en los preámbulos de los mismos, o bien cuando se

88 De VegA, P.: La reforma constitucional y la problemática del Poder Constituyente, Tecnos, Madrid, 1991, págs. 283-284. En este sentido, revisten también gran interés, las reflexiones del profesor Ruipérez que se situan en la senda marcada por su maestro el profesor De Vega: RuIPEREZ, J.: "Algunas consideraciones sobre la reforma constitucional" en Revista de Estudios Políticos, núm. 75, 1992, págs. 233-258. 
presentan como supuestos indiscutibles de la ideología social imperante, esos principios y valores legitimadores del ordenamiento, tendrán por fuerza que configurarse como zonas exentas al poder de revisión, y adquirir, por tanto, el indudable carácter de límites materiales implícitos a todo poder de reforma" ${ }^{89}$.

Entender que el artículo 168 otorga al poder de reforma la facultad de modificar totalmente el ordenamiento conduce a consagrar un despropósito que jurídicamente repugna a la lógica global del Estado Constitucional. Por ello dicho precepto, en el marco de una Constitución normativa, sólo puede ser interpretado, como muy bien ha visto el profesor Ruipérez en el sentido de que el poder de reforma puede alterar toda la literalidad de la Constitución siempre y cuando respete los mencionados principios y valores legitimadores del Estado Constitucional en general, y los de la fórmula política del Estado español, en particular ${ }^{90}$.

Ahora bien, que la existencia de estos límites materiales implícitos al poder de reforma, sea una consecuencia obligada del concepto político de Constitución y de la lógica interna del Estado constitucional, no impide que la enumeración y la especificación de los mismos sea una tarea compleja. Tarea, que innecesario es recordarlo, desborda con creces el propósito de este estudio sobre los derechos históricos. En todo caso, y para nuestro tema, nos basta con señalar que existen unos límites materiales implícitos que operan en el seno de todo Estado Constitucional y son comunes, por tanto, a todos los ordenamientos. Dichos límites vienen configurados por los tres principios esenciales e inherentes a esta forma histórica de Estado: el primero de ellos, es el principio democrático según el cual la soberanía reside en el pueblo, titular indiscutido e indiscutible del poder constituyente ${ }^{91}$; los otros dos encuentran su fundamento en aquél, y son el principio político liberal que se manifiesta en la garantía de la libertad mediante el reconocimiento de los derechos y las libertades fundamentales de los individuos y en la organización del Estado conforme al principio de separación de poderes; y el principio jurídico de supremacía constitucional, que se traduce en la existencia de un

89 De VegA, P.: La reforma constitucional... ob. cit., pág. 285. En el mismo sentido se pronuncia el profesor Balaguer, uno de los más cualificados estudiosos de nuestro sistema de fuentes: "Existen límites materiales a la reforma que se derivan de la interdicción de desnaturalizar el orden constitucional vigente. La falta de explicitación de los mismos no impide su eficacia jurídica que se manifiesta en la imposibilidad de aceptar, bajo el régimen constitucional vigente y desde una perspectva jurídica, determinadas reformas que desfiguren el núcleo esencial de la Constitución". Balaguer, F.: Fuentes del Derecho, Tecnos, Madrid, 1992. Vol. II, pág. 39.

90 Ruiperez, J.: Constitución y autodeterminación, Tecnos, Madrid, 1995. Capítulo 4.

91 Así, se refiere Pedro de Vega, al artículo 1. 2 de la Constitución española (la soberanía nacional reside en el pueblo), cuya supresión, no podría interpretarse como una operación de revisión, "sino como un acto revolucionario de destrucción de la Constitución existente" (pág. 286). Importa, no obstante, precisar que dicho artículo puede ser alterado en su redacción o literalidad (piénsese por ejemplo en la supresión del adjetivo nacional, o de su inciso final, del que emanan los poderes del Estado) siempre que se mantenga el principio en cuestión (la soberanía reside en el pueblo español). 
procedimiento específico de reforma y de control de constitucionalidad de las normas.

De lo expuesto hasta aquí, podemos concluir afirmando que, desde la perspectiva de la Teoría de la Democracia, una concepción sustantiva o material de la misma, y no meramente formal o procedimental, nos conduce, inevitablemente, a la única Teoría de la Constitución compatible con aquella, esto es, la que se basa en un entendimiento del Poder de Reforma como poder constituido y limitado.

\subsection{Los límites materiales al Poder Constituyente}

Y llegados a este punto, debemos extraer las últimas consecuencias de la tesis anteriormente expuesta. Si la Teoría de la Democracia, entendida en sentido sustantivo, como orden material de valores, nos obliga a concebir el Poder constituyente derivado o poder de reforma como un poder limitado, lo mismo ocurre respecto al Poder Constituyente originario ${ }^{92}$.

El Poder Constituyente originario, por definición y por su propia naturaleza de poder soberano, es un poder absoluto e ilimitado. Ahora bien, lo cierto es que si con su intervención en la historia pretende alumbrar un régimen constitucional, está sometido a unos límites. Naturalmente que como poder fáctico y existencial puede quebrantarlos y por lo tanto no le limitan en sentido jurídico. Pero las consecuencias del no respeto a esos límites son muy claras: el producto resultante de su actuación no podrá ser considerado como una Constitución (racional-normativa o democrática). Con unos ejemplos se entiende perfectamente. Si el Poder Constituyente establece que los individuos negros son inferiores a los blancos y que en consecuencia no son titulares del derecho a la vida, ese texto no es una Constitución. Lo mismo ocurriría en el caso de que el pueblo soberano determinase que la única fuente válida del derecho es la autoridad divina y los intérpretes de ésta.

Dicho con otras palabras, para que el Poder Constituyente alumbre una verdadera Constitución, desde una perspectiva jurídica, es preciso que respete aquellos contenidos esenciales de la Constitución que, anteriormente, hemos considerado como límites materiales implícitos al poder de reforma, esto es, el principio democrático, el principio liberal, y el principio de supremacía constitucional.

En el supuesto de que el Poder Constituyente introdujese en el texto constitucional disposiciones que pugnen con esos principios, habría que concluir que se trata de normas constitucionales inconstitucionales (o bien, negar la condición de constitucional a tal texto). Pues bien, eso es lo que ha ocurrido en el caso de la DAP. El constituyente ha introducido una categoría, los derechos históricos, que pugna con el principio de legitimidad democrá-

92 En este sentido, Diez PicAzo, L.M.: "Límites internacionales al poder constituyente" en Revista Española de derecho Constitucional, núm. 76, 2006, págs. 9-32. 
tica. Y, desde la perspectiva que acabamos de defender, de nada sirve afirmar que puesto que se trata de una categoría recogida en la Constitución, hay que admitir, por definición, su constitucionalidad. Si todo lo anterior tiene algún sentido, la respuesta es justamente la contraria.

En mi opinión, - - y esta es la tesis central de este ensayo- la DAP es un caso paradigmático de norma constitucional inconstitucional. Y ello por la razón evidente de que introduce un criterio de legitimidad incompatible con la Constitución democrática. Dicho con otras palabras, en un régimen constitucional democrático, la historia ni puede ser fuente de derechos, ni puede limitar el alcance del principio democrático. La asunción de la legitimidad histórica supone la destrucción de la Constitución democrática. Y frente a esto no vale afirmar cómo hace el Tribunal Constitucional que la recepción constitucional de los derechos históricos supone su transformación. Y ello porque dicha transformación implicaría, igualmente, la imposibilidad de seguir configurándolos como derechos históricos.

El análisis de la DAP debe hacerse "desde la perspectiva de la dialéctica mas amplia entre historicismo y racionalidad normativa" ${ }^{93}$. Y desde esa perspectiva, inevitablemente se llega a concluir la radical incompatibilidad entre ambas. En este sentido, hay que reconocer que los historicistas llevan razón cuando advierten que con la DAP, lo que hace la Constitución es negarse a sí misma.

\subsection{LA DISTINCIÓN ENTRE "NORMA CONSTITUCIONAL INCONSTITUCIONAL" Y "NORMA DE EXCEPCIÓN CONSTITUCIONALMENTE PREVISTA".}

El hecho de que la tesis que defiende la hipotética existencia de «normas constitucionales inconstitucionales" no haya tenido eco en nuestro país, puede deberse, entre otras causas o razones, a que cuando esta fue planteada en sede doctrinal se hizo erróneamente. Así, las profesoras Pilar Mellado y Yolanda Gómez defendieron como un supuesto de norma constitucional inconstitucional ${ }^{94}$, la disposición contenida en el artículo 57 de la Constitución

93 Tudela Aranda, J.: "La Disposición Adicional Primera de la Constitución y los nuevos Estatutos de Autonomía...ob.cit., pág. 144

94 Mellado Prado, P., Y Gomez Sanchez, Y.: "En torno a la posible inconstitucionalidad del apartado primero del artículo 57 de la Constitución española" en Diario La Ley, 23-XI-84. La profesora Gómez Sánchez en su meritoria aportación a los debates sobre la reforma constitucional organizados conjuntamente por el Consejo de Estado y el CEPC no llega a rectificar, pero sí que parece matizar mucho su tesis inicial: "La tesis de la posible inconstitucionalidad de una norma inserta en el propio Texto Constitucional implica que aunque una norma se encuentre en la Constitución ello no impediría que fuera nula si contraviniera principios constitucionales fundamentales, informadores de todo el ordenamiento jurídico y por ello preeminentes incluso respecto a normas constitucionales concretas. A pesar de poseer lógica interna esta tesis presenta, sin duda, el inconveniente de precisar una graduación de las normas y principios constitucionales conforme a criterios ajenos al Derecho positivo y aunque en el tema de la igualdad entre hombres y mujeres la conclusión favorable a la equiparación se deduce sin dificultad es cierto que la 
referido a la Sucesión a la Corona y en la que se discrimina a la mujer, en cuanto pugna con la prohibición de discriminación por razón de sexo establecida en el artículo $14{ }^{95}$.

Sin embargo, en este caso, de lo que se trata es de una excepción constitucionalmente prevista a una norma constitucional, y en este sentido, tan constitucional es la regla establecida en el artículo 14 como la excepción prevista en el artículo 57. De entender lo contrario, la misma institución monárquica resultaría inconstitucional por discriminatoria, lo cual evidentemente conduce a un resultado absurdo. En definitiva, las reglas constitucionales pueden ser objeto de una excepción siempre que esta esté también recogida en el Texto Constitucional ${ }^{96}$. En tales casos no cabe hablar de normas cons-

generalización de la tesis de la inconstitucionalidad de normas constitucionales resulta muy difícil. Por ese motivo, creo que, sin negar el valor interpretativo de la tesis que comento resulta jurídicamente más viable acudir a otros procedimientos jurídicos para lograr dicha igualdad como puede ser el de la reforma constitucional.(...) Con todo, el fundamento material de la tesis a la que hago referencia sigue siendo válido en la actualidad puesto que se trata de detectar aquellas antinomias o contradicciones internas del propio texto. (...)(He)mencionado diferenciaciones estructurales propias de la Monarquía que hay que distinguir de aquellas otras que no diferencian sino que discriminan por carecer de toda justificación razonable. La mayoría de los textos constitucionales actuales integran excepciones que no rompen con la lógica interna del Texto Fundamental si cuentan con un objetivo compatible con los demás principios constitucionales y si resulta proporcional al fin perseguido. Nada de eso acontece en el caso de la preferencia del varón sobre la mujer en el orden sucesorio".Gomez SANCHEZ, Y.: "La sucesión a la Corona: la reforma del artículo 57.1 CE" en El Informe del Consejo de Estado sobre la reforma constitucional. Texto del informe y debates académicos. Consejo de Estado-CEPC, Madrid, 2006, pág. 393. También, recientemente Jorge de Esteban ha escrito: «la discriminación por razón de sexo en lo que se refiere a la sucesión de la Corona es, según la doctrina alemana, una de esas cláusulas constitucionales inconstitucionales que se pueden ver en algunas Constituciones puesto que el art. 57 citado va en contra del artículo 14". El Mundo, 8-V-05. En contra SOLOZABAL, J.J: “Tan constitucional es la regla general de la igualdad del artículo 14 CE como la regla especial de la preferencia del varón del artículo 57 de la misma Constitución". EL País, 15-V-05.

95 «La sucesión en el trono seguirá el orden regular de primogenitura y representación, siendo preferida siempre la línea anterior a las posteriores; en la misma línea, el grado más próximo al más remoto; en el mismo grado, el varón a la mujer" (art. $57.1 \mathrm{CE}$ ). "Los españoles son iguales ante la ley, sin que pueda prevalecer discriminación alguna por razón de nacimiento, raza, sexo, religión, opinión, o cualquier otra condición o circunstancia personal o social" (art. 14 CE)

96 El carácter de norma constitucional especial de la DAP ha sido defendido y teorizado por Porres Azkona, J.: Política y Derecho. Los Derechos Históricos Vascos, IVAP, Oñate, 1992. También, aunque con otro sentido, LAPORTA, F.J. "Los derechos históricos en la Constitución...ob.cit, pág. 45. "El régimen especial que permite diseñar la DAP es ni más ni menos un régimen especial de Comunidad Autónoma. El País Vasco y Navarra configurarían así una situación jurídica especial en lo que respecta a sus regímenes autonómicos". Págs. 47-48. La DAP tiene una naturaleza de lex specialis: "La especialización se operaría respecto a la Constitución misma como régimen general para todos los demás". Págs. 48-49. Esta interpretación se confirma por la ubicación sistemática de la disposición. Son precisamente, las disposiciones adicionales las que suelen contener las excepciones a las reglas generales previstas en el articulado. También la literalidad del texto conduce a este entendimiento de la DAP como lex specialis (indeterminada en cuanto a su alcance) y ello porque no se prevé que la actualización foral deba llevarse a cabo "Según" la Constitución, sino solo "en el marco" de aquella, sin que quede claro la amplitud de ese marco, esto es lo que puede y lo que no puede ser excepcionado. En el mismo sentido, Saiz Arnaiz llega a calificarla de "cláusula de auto-ruptura" que incorpora una excepción de la regla general para 
titucionales inconstitucionales. Es el principio de especialidad y no el de jerarquía el que explica la relación entre ellas.

Ahora bien, si las normas constitucionales admiten excepciones, lo que de ninguna forma las admite es el principio mismo de legitimidad, y los derechos históricos, por su propia configuración, pugnan con la legitimidad democrática. Si el Pueblo es la fuente de la legitimidad, la Historia no puede serlo. Y a la inversa. Dicho con mayor claridad y contundencia, lo que el constituyente no puede hacer es excepcionar el principio de legitimidad propio de la constitución racional-normativa, esto es, el principio democrático. Se pueden excepcionar preceptos constitucionales concretos pero no la Constitución en su totalidad como decisión unitaria.

La distinción efectuada por Schmitt entre Constitución y Ley Constitucional resulta, en este ámbito, muy esclarecedora. El constituyente puede establecer excepciones a las leyes constitucionales, y dichas excepciones son plenamente constitucionales. Lo que resulta absurdo es admitir que pueda excepcionar la Constitución misma.

Como es sabido, junto con Herman Heller y Rudolf Smend, Carl Schmitt fue uno de los autores más representativos de la reacción contra el extremado formalismo jurídico en que había desembocado la dogmática alemana del derecho público (Gerber, Laband, Jellinek, Kelsen). La clave de su obra reside en el decisionismo. Para Schmitt la Constitución es decisión, no norma. "La esencia de la Constitución no está contenida en una ley o norma. En el fondo de toda normación reside una decisión política del titular del poder constituyente ${ }^{97}$. . Como ha señalado García Pelayo, este planteamiento, que trata de superar el hueco formalismo en que se hallaba la Teoría del Estado, conduce al intento de captar el concepto de Constitución, no mediante un análisis de sus partes integrantes, sino a través de una intuición esencial que la revele como una totalidad en función de la cual se expliquen luego las partes componentes ${ }^{98}$. La idea de totalidad se logra con el concepto de «decisión política fundamental». Ella impide la disolución de la Constitución en un complejo inconexo de normas. Ella garantiza la unidad ontológica y jurídica de la Constitución. "Es necesario hablar de la Constitución como de una unidad, y conservar entre tanto un sentido absoluto de Constitución". Esta idea de Constitución le lleva a diferenciar la misma de las "leyes constitucionales":

hacer posible un régimen jurídico especial. SAIZ ARNAIZ, A.: "La titularidad de los derechos históricos y las reformas...ob.cit. pág. 135. Comparto con los autores citados la premisa de que la DAP es una lex specialis, ahora bien en la medida en que la especialidad consiste en un título o principio legitimador distinto del democrático (que es el propio de las restantes Comunidades Autónomas) creo que se trata de una excepción inconstitucional, y ello porque lo que se pretende excepcionar es la decisión política fundamental del Constituyente a favor de la democracia, como único principio legitimador del poder y del derecho.

97 Sснмітт, C. Teoría de la Constitución, versión española de Francisco Ayala, Alianza Editorial, Madrid, 1982. p. 47.

98 Garcia Pelayo, M. "Derecho Constitucional comparado", en Obras Completas, CEC, Madrid, 1991. p. 296. 
"Solo es posible un concepto de Constitución cuando se distinguen Constitución y ley constitucional. No es admisible disolver primero la Constitución en una pluralidad de leyes constitucionales concretas y después determinar la ley constitucional por algunas características externas o acaso por el procedimiento de reforma ${ }^{99}$. La Constitución vale en cuanto acto de voluntad de un poder constituyente. Las leyes constitucionales sólo cobran sentido en relación con la decisión política fundamental. Esto es, se encuentran subordinadas a ella y si pugnan con ella son nulas. Schmitt ilustra sus tesis con ejemplos de la época. Así, analizando la Constitución alemana de 1919, afirma que la decisión política fundamental en ella afirmada, es la hecha a favor de la democracia, del federalismo y del liberalismo. En esta triple decisión consiste la Constitución de Weimar, todo lo demás son meras leyes constitucionales subordinadas a aquella ${ }^{100}$. Esto quiere decir que cualquier ley constitucional contraria a la democracia, al federalismo o al liberalismo es inconstitucional y como tal nula.

Sirviéndonos de esta distinción de Schmitt, que nos parece impecable desde un punto de vista conceptual, y absolutamente necesaria, desde un punto de vista práctico, para garantizar el sentido unitario de la constitución como expresión de un orden material de valores, como un orden único, entendemos por normas constitucionales inconstitucionales las que contradicen la Constitución, no las que se oponen a Leyes Constitucionales concretas. Y

99 Sснмітт, C. Teoría . . ob. cit., págs. 47 y 45.

100 De la distinción entre Constitución y leyes constitucionales, Schmitt deduce, entre otras, las siguientes afirmaciones: a) La utilización del procedimiento de reforma constitucional sólo es posible en relación con las leyes constitucionales. La Constitución no es susceptible de reforma porque una decisión política fundamental, según él, no puede enmendarse sino anularse, sustituirse por otra distinta. Hablando de la Constitución de Weimar dirá: "El hecho de que la Constitución de Weimar sea una Constitución y no una suma inconexa de prescripciones particulares reformables según el artículo 76. . . consiste sólo en ésta decisión existencial totalitaria del pueblo alemán. . . En vías del artículo 76 pueden reformarse las leyes constitucionales, pero no la Constitución como totalidad". Admitir lo contrario supone reducir la Constitución al procedimiento de reforma, al citado artículo 76, y vaciarla, por tanto, de cualquier contenido material. b) En situaciones excepcionales (guerras, catástrofes naturales. . . etc.), las leyes constitucionales pueden ser suspendidas. Por el contrario, la Constitución, como totalidad, no puede ser jamás suspendida. Precisamente la legitimidad de la suspensión de las leyes constitucionales reside en la necesidad de conservar la Constitución. Es decir, cuando el mantenimiento de la Constitución como totalidad exige la suspensión de algunas leyes constitucionales, la adopción de tales medidas suspensivas se halla justificada. c) La lealtad a la Constitución, no significa adhesión a todos los preceptos contenidos en las leyes constitucionales, sino vinculación positiva a la decisión política fundamental. La lealtad a las leyes constitucionales carece de sentido. En cuanto todas ellas pueden ser reformables, nos encontramos ante la imposibilidad de una vinculación material. Una promesa de lealtad en blanco, o todo lo más, al precepto que establece el procedimiento de reforma, no sirve en modo alguno para crear sentimiento constitucional. Ello sólo es posible respecto a la Constitución como decisión política fundamental. Así, en relación al juramento de la Constitución alemana previsto por la misma, afirmará: «Este juramento significa, pues, un juramento de la Constitución entendida en sentido propio y positivo, es decir, un reconocimiento, confirmado por el juramento, de las decisiones políticas fundamentales que se hallan contenidas en la Constitución de Weimar y que hacen de ella una Constitución en sentido sustancial». SchмiтT, C. Teoría . . . ob. cit., págs. 47-51. 
desde esta perspectiva la apelación a la legitimidad bistórica inherente en la noción de derechos históricos contradice la decisión política fundamental a favor de la democracia en que la Constitución se basa.

El propio Schmitt en otra obra clásica y demoledora sobre la Constitución de Weimar advirtió de los peligros y las consecuencias de asumir en un mismo Texto Constitucional, diferentes principios de legitimidad. Cuando ello ocurre: "La Constitución se desvanece en sus contradictorios elementos interiores y posibilidades de interpretación, y ninguna ficción normativa de 'unidad' evita que cualquier grupo en pugna se adueñe de las partes o expresión constitucional que parezca más apropiado para destruir al partido adversario, también en nombre de la Constitución. Entonces, legalidad, legitimidad y Constitución, en vez de prevenir la guerra civil, sólo contribuirían a su agravación" ${ }^{101}$.

Si lo anterior tiene algún fundamento, la conclusión no puede ser más clara: la DAP es una norma constitucional inconstitucional. Y ello por referencia no a principios ajenos al derecho positivo vigente, esto es al derecho natural o a concepciones subjetivas de la justicia, sino a la propia Constitución. Y no creo que esta afirmación conduzca ni a resultados absurdos ni a un golpe de estado encubierto. Y digo esto en respuesta a la crítica formulada a esta categoría por el profesor Fernando Rey: "No me parece que exista lugar alguno en nuestro ordenamiento constitucional para la categoría alemana de las disposiciones constitucionales inconstitucionales. Tampoco me parece útil puesto que, de seguirse, conduciría al absurdo de considerar (por parte de quién, además, ¿quizás el Tribunal Constitucional? ¿Con arreglo a qué procedimiento, instado por quién o quiénes? que el artículo (X) aún sin haber sido reformado por el procedimiento constitucionalmente previsto es inconstitucional y, por tanto, nulo, de modo que no sería aplicable (eso sería tanto como una especie de 'golpe de estado en nombre de la Constitución)". ${ }^{102}$

Es evidente que correspondería al Tribunal Constitucional formular la declaración de inconstitucionalidad de una norma constitucional. Y podría hacerlo en la resolución de cualquier tipo de proceso constitucional en que fuera de aplicación la norma de que se trate. En nuestro caso, el Tribunal, como ya hemos visto, ha tenido que enfrentarse, a la DAP. En cualquiera de esos supuestos podría haber declarado la inconstitucionalidad de la DAP y con ello, a mi juicio, lejos de dar un golpe de Estado, habría restablecido la unidad de la Constitución y obrado, en consecuencia, como su supremo garante.

101 Sснмітт, C.: Legalidad y legitimidad (1932), Comares, Granada, 2006, pág. 94. El insigne jurista nazi, al que se lee con asco y admiración simultánea, se refería a la contradicción entre la legitimidad democrático-parlamentaria (a la que se refiere simplemente como legalidad) y la legitimidad plebiscitaria por el defendida. Schmitt criticaba "la duplicidad de dos sistemas de fundamentación jurídica distintos que son el del sistema de legalidad del Estado legislativo parlamentario y el de legitimidad de la democracia plebiscitaria; la posible carrera entre ambos no es sólo una competición de instancias, sino una lucha entre dos tipos de Derecho", pág. 66.

102 ReY, F.: "Derecho de sucesión en la Corona y discriminación por razón de sexo: análisis de la posible supresión de la preferencia sucesoria de los varones" en El Informe del Consejo de Estado...ob. cit., pág. 423 y 424. 
Aunque esta tesis pueda sorprender por su heterodoxia, debo decir que no es ajena a determinados planteamientos del Tribunal Constitucional formulados en otros ámbitos. No se puede ni se debe olvidar que aunque, formalmente amparado en el principio de interpretación armónica y sistemática del Texto Constitucional, ha habido ocasiones en que el Tribunal, materialmente, ha dejado sin efecto preceptos constitucionales concretos. Así, y a título de ejemplo, el Tribunal Constitucional tuvo que pronunciarse sobre la constitucionalidad de la inmunidad parlamentaria que, como es sabido, se halla prevista en un precepto constitucional. Se trata de una categoría difícil de armonizar con el principio de Estado de Derecho, puesto que provoca indefensión de los ciudadanos. La inmunidad parlamentaria determina que si un ciudadano es víctima de un delito cometido por un parlamentario y la Cámara a la que este pertenece no autoriza su procesamiento por el Tribunal Supremo, el delito no puede ser perseguido. El Tribunal, obviamente, ha rechazado esta interpretación por ser incompatible con el Estado de Derecho. Ahora bien, con esa jurisprudencia, sin declarar la inconstitucionalidad del precepto constitucional, el Tribunal lo ha vaciado de contenido. ¿No podría haber hecho algo parecido con la DAP?

Finalmente, es preciso analizar otra posible objeción al núcleo de la tesis que defiendo. Y es la relativa al principio de conservación de la norma que si opera en relación con la ley, aun más en este otro tipo de supuestos. La presunción de legitimidad de la norma constitucional y el principio de conservación de esta exige al Tribunal Constitucional intentar buscar un significado de la DAP compatible con la Constitución, atribuirle un sentido constitucionalmente aceptable. Solo en el caso de que tal interpretación conforme fuera absolutamente imposible, podría el Tribunal Constitucional formular la excepcional y trascendental declaración de inconstitucionalidad de la DAP.

Frente a esta objeción hay que subrayar que la DA Primera con independencia de su ambigüedad e indeterminación, no puede dejar de configurarse como una norma declarativa de un principio de legitimidad histórica. Los derechos históricos o son eso o no son nada. Si admitimos que se fundamentan en la Constitución y no en la Historia, entonces es que ya no son históricos. No se trata de realizar una inaceptable interpretación de la Constitución en virtud de los Estatutos, pero cuando en el Estatuto vasco o navarro se afirma que la aceptación de la autonomía "no implica renuncia del Pueblo Vasco (o navarro) a los derechos históricos que como tal le hubieran podido corresponder en virtud de su historia", se hace referencia a una realidad normativa que es la reflejada en la DAP: esto es, que la Historia puede ser fuente de derechos para algunos territorios, esto es, para las personas que viven en ellos. Y que, en virtud de esa Historia, y eso es lo decisivo, el resto de los ciudadanos de España no podrán nunca disfrutar. En este contexto, el examen de la DAP nos muestra que lo de menos es la dificultad de precisar el contenido de dichos derechos, puesto que lo fundamental es su invocación como titulo legitimador de un hecho diferencial del que siempre se podrán 
deducir "diferencias" respecto al resto de Comunidades. En definitiva, la inconstitucionalidad reside en la apelación a la historia para justificar no ya la diferencia, sino la desigualdad; en la consagración de una desigualdad contraria al orden material de valores del constitucionalismo, y fundamentada además en un título histórico.

Recordaba el maestro Tomás y Valiente que "promulgada la Constitución, cualquier forma de legitimidad historicista queda sustituida por la única forma posible de legitimidad admisible en un Estado democrático de Derecho, esto es la derivada del propio texto constitucional". Lo ocurrido durante los últimos treinta años nos pone de manifiesto que la DAP ha discurrido por una senda diferente. Se pudo creer en su momento que la recepción de los fueros o derechos históricos en la Constitución y la actualización de estos mediante los Estatutos de Autonomía se traduciría en el reconocimiento de alguna singularidad foral compatible con los valores constitucionales y con la realidad socio-económica del presente. Y que con ello la cuestión foral, esto es el conflicto fueros-constitución quedaría definitivamente resuelto. En el 2008 nadie puede seriamente seguir albergando esas esperanzas. Los derechos históricos han superado su estricta función de remisión a alguna singularidad foral para transformarse en presupuestos legitimadores del autogobierno. Se han utilizado en Cataluña y en Valencia para legitimar reivindicaciones que exceden del marco constitucional y ello porque a pesar de las interpretaciones bienintencionadas pero ingenuas de los mismos, se trata de derechos que por su propia naturaleza no pueden concebirse como limitados por la Constitución. No tienen más límite que la propia decisión del pueblo (navarro, vasco, catalán) como sujeto histórico. Y con esa conversión (en cierta medida previsible) han devenido en radicalmente incompatibles con el Texto Constitucional. Las dudas sobre la posible compatibilidad existente entre Constitución y derechos históricos si alguna vez pudieron existir, se han desvanecido por completo. Se trata de categorías incompatibles.

El constituyente de 1978, presionado por el terrorismo etarra y con la esperanza de integrar al nacionalismo vasco en el consenso constitucional, fue débil y cedió. Permitió que el historicismo penetrara en nuestra Constitución y este, una vez dentro, ha desplegado todos sus efectos. Aquella cesión fue grave. Supuso olvidar que la Constitución democrática como orden material de valores surgió por oposición al paradigma político del Antiguo Régimen, donde el principio de legitimidad histórica revistió una importancia decisiva. El concepto mismo de Derecho propio de un régimen constitucional es incompatible con la idea de Derecho defendida por la Escuela Histórica. E insisto, la categoría de derechos históricos carece, a su vez, de sentido, fuera de esa comprensión historicista ${ }^{103}$.

103 En el manifiesto fundacional de la Escuela Histórica, Savigny expone esa incompatibilidad: "El contenido del Derecho está dado por todo el pasado de la nación, no es producto de una voluntad de tal suerte que puede ser así o de otro modo según el caso, sino que surge de la más íntima esencia de la nación y de su historia". 
La Constitución, los Estatutos, el autogobierno no pueden fundamentarse simultáneamente en la voluntad ciudadana y en la historia. De hecho, por fundamentarse en la historia, el margen de actuación del principio democrático ha sido constreñido al máximo. La voluntad del pueblo queda acotada por la Historia. Como denuncia Tudela Aranda: "A ese electorado se le deja, en todo caso, un espacio reducido, previamente acotado por todo aquello que de manera indubitable corresponde ocupar a la legitimidad histórica" 104.

La conclusión de todo lo anterior es clara: el Tribunal Constitucional está legitimado para declarar la inconstitucionalidad de una norma constitucional, y, en el caso que nos ocupa, en nuestra opinión y por las razones expuestas, podría y debería haber anulado (o, al menos, dejado sin efecto) la DAP. Ahora bien, si desde una perspectiva estrictamente jurídica creo que dicha tesis es correcta y acertada, reconozco que políticamente resulta inviable. Por ello, y desde una perspectiva política, la forma óptima de resolver la inconstitucionalidad de una norma establecida por el Constituyente originario, es la actuación del Constituyente derivado, esto es del Poder de Reforma.

\section{LA NECESARIA REFORMA CONSTITUCIONAL DE CARÁCTER "DEPURATIVO".}

Desde un punto de vista histórico, lo que caracteriza a las constituciones y las distingue del resto de normas jurídicas, es que son normas de crisis. Las constituciones nacen siempre en el contexto de las grandes crisis históricas de la vida de los pueblos. El Poder Constituyente es un poder de crisis porque actúa siempre en los momentos de mayores convulsiones políticas y sociales. Ese tiempo de crisis, nos recuerda el profesor Carlos de Cabo, "es el propiamente 'constitucional' en el sentido de que es el único en el que las Constituciones surgen como necesidad" ${ }^{105}$. Ello contrasta con el dato indiscutible de que para elaborar un buen Texto Constitucional se requieren unas condiciones de tranquilidad, sosiego y reflexión. Por eso podemos decir que las constituciones surgen siempre cuando tienen que hacerlo, pero eso ocurre en el peor momento posible. Nada de extraño tiene, por tanto, que los Textos Constitucionales, lejos de ser obra perfecta de la racionalidad humana, presenten numerosos defectos. Defectos que traen causa de las críticas circunstancias que rodearon su alumbramiento, en definitiva, de su tiempo. En este contexto, la Reforma Constitucional se configura como el instrumento principal, sino único, para paliar esas deficiencias, lagunas y contradicciones.

La DAP fue, indiscutiblemente, una norma de crisis, gestada entre la presión terrorista y la esperanza de integrar al PNV en el consenso constitu-

104 Tudela Aranda, J.: "La Disposición Adicional Primera y los nuevos Estatutos de Autonomía ...ob.cit., pág178.

105 De CABO, C.: La reforma constitucional, Trotta, Madrid, 2006. 
cional. Esa crisis dista mucho de haber sido resuelta. Por ello mismo, la DAP ha demostrado también su inutilidad desde este punto de vista estrictamente pragmático.

En diversos lugares he defendido la necesidad de llevar a cabo una reforma constitucional amplia en el sentido planteado por el Consejo de Estado en su meritorio Informe con el que respondió a las consultas formuladas por el Gobierno de la Nación en la pasada Legislatura ${ }^{106}$. Esa reforma tendente a consolidar nuestro modelo de organización territorial en clave federal, es el contexto lógico en el que la DAP, junto con otras muchas disposiciones del Título VIII, debiera ser suprimida. Como ha expuesto el Consejo de Estado, la consolidación del Estado Autonómico exige cerrar en sede constitucional el modelo de organización territorial. Ello exige enterrar definitivamente el principio dispositivo llevando al Texto Constitucional, no sólo la denominación de las Comunidades Autónomas existentes sino también su ámbito competencial ${ }^{107}$. Dicho con otras palabras, cualquier modificación del mapa autonómico o del techo competencial de las Comunidades debiera requerir en el futuro, una reforma constitucional. Para lograr ese objetivo la depuración del texto constitucional exigiría eliminar todas las disposiciones que pudieran conducir a un resultado contrario, y entre ellas cabe destacar la DA Primera y ello por dos razones: la primera porque se ha utilizado como un procedimiento de acceso a la autonomía; la segunda porque pretende utilizarse indefinidamente como un título habilitante de competencias y de diferencias entre Comunidades. En la medida en que se pretende cerrar el mapa y el sistema de reparto competencial, la DA Primera pierde cualquier virtualidad, salvo la de consagrar unas diferencias entre ciudadanos y territorios en virtud de la Historia que, como ha quedado expuesto, no resulta constitucionalmente admisible.

Las reformas estatutarias expuestas en el epígrafe quinto convierten a la reforma constitucional en una operación necesaria para la supervivencia del Estado Constitucional. La DAP introdujo la simiente confederal en el Texto Constitucional. La reforma constitucional tiene que cerrar la puerta definiti2005.

106 Tajadura, J., y Roura, S (dir.).: La Reforma Constitucional, Biblioteca Nueva, Madrid,

107 "La cuestión que para concluir la Constitución se ha de resolver - escribe en relación con este tema el Presidente del Consejo de Estado- es la gran cuestión pendiente desde el comienzo: la de si todas las Comunidades han de gozar del mismo nivel de autonomía (suponiendo que quepa hablar de gozo) o si, por el contrario, han de perpetuarse las diferencias competenciales entre ellas". RUBIO LLORENTE, F.: "Sobre la conveniencia de terminar la Constitución antes de acometer su reforma" en La forma del poder, CEC, 1993, pág. 172. El profesor Rubio Llorente advierte con acierto que "el mantenimiento de un verdadero Estado necesita también de la aceptación de la homogeneidad o simetría en la disposición territorial de su organización", y ello porque "resulta técnicamente difícil organizar un poder que no se distribuye de modo igual en todo el territorio". Y a mayor abundamiento, el Presidente del Consejo de Estado advierte que "el espíritu de la Constitución lleva a la abolición de toda diferencia, porque la equiparación competencial de todas las Comunidades Autónomas es la solución congruente con el principio de igualdad". 
vamente a la posible conversión de España en una confederación (en sentido fiscal, ya lo es ${ }^{108}$ ). Con toda razón, Tudela Aranda afirma que el «historicismo estatutario estaría ganando la partida a la racionalidad constitucional ${ }^{109}$. En realidad, ya la ha ganado. La historia ha vencido a la racionalidad normativa. Los Estatutos historicistas han ganado ya una importante batalla a una Constitución débil que, incomprensiblemente, acogió el principio de doble legitimidad en su DAP. En este contexto la reforma constitucional resulta imprescindible para restablecer la supremacía normativa de la Constitución y la plena efectividad del principio democrático.

El profesor Sosa Wagner denuncia el sinsentido que supone apelar a derechos históricos en el siglo xxi. La cita es larga, pero por su agudeza y lucidez merece ser reproducida: "Hurgar en estos derechos históricos —escribe el Catedrático de León- nos lleva a los derechos contenidos en los fueros - como ocurre expresamente en el Estatuto de Valencia- que eran una amalgama de disposiciones de derecho privado y público, de las que sólo pueden sobrevivir en los tiempos modernos algunas de las primeras, difícilmente las segundas, pues serían incompatibles con las sacudidas revolucionarias que el derecho público en general ha experimentado desde finales del siglo xviII. En la idea de fuero anidaba la 'exención', la 'inmunidad' frente al poder, también la de 'pacto' o acuerdo con un señor que se comprometía a aceptar determinadas reglas y costumbres. Será pues un privilegio frente a la Corona que se estaba imponiendo como poder emergente y que dará como resultado el Estado. Por ello quien no acepta el régimen constitucional en el siglo XIX — el carlismo- se aferra a tales fueros para cobijar en su concha sus diferencias y no dejarse contaminar por el régimen constitucional, por las libertades, por la democracia y el sufragio, limitado primero, universal después. Cuando se pierdan definitivamente con la ley de 1876, se tratará de reconstruir el privilegio y el pacto fiscal y nacerá el Concierto. Una reivindicación que permanecerá intacta y que se activará de nuevo por el nacionalismo vasco (...) La siembra — que ha resultado fecunda de tal pensamiento en los huertos de otros nacionalismos hispanos- pone de manifiesto lo arraigado de ese deseo de singularidad, de exención o de inmunidad, de acuerdo o pacto, que ahora se llama 'bilateralidad'. Los frutos obtenidos se trasladarán a las demás CC. AA., porqué ¿quién va a negar derechos históricos a astures, cántabros, castellanos, andaluces, toledanos, mallorquines, leoneses, etc.? Todo ello es incompatible con el Estado moderno y muy especialmente con el Estado federal ${ }^{110}$. Huelgan comentarios. Los privilegios, el pactismo, en definitiva, esa bilateralidad que es hoy un lugar común en los nuevos Estatutos, son incompati-

108 En el Estado Federal, la Federación ingresa y reparte. En la Confederación las partes recaudan y pagan una parte a la Confederación para sufragar los gastos de política exterior y de defensa.

109 Tudela Aranda, J.: "La Disposición Adicional Primera y los nuevos Estatutos de Autonomía...ob.cit, pág. 144.

110 Sosa Wagner, F.: El Estado fragmentado... ob. cit. págs. 149-150. 
bles con el principio federal (y con el de solidaridad y cooperación), es más lo quiebran, y de esa forma, nos sitúan en la senda confederal.

El profesor Sosa Wagner nos recuerda cómo todos los países federales serios han suprimido en cuanto han podido figuras similares a los derechos históricos: "Así ocurrió con lo que la doctrina alemana llamó a finales del siglo XIX Reservatrechte, derechos reservados, un compendio de privilegios antiguos que incluían embajadas', presidencias o competencias exclusivas en el correo, el telégrafo o los ferrocarriles, que Bismarck ofreció a Baviera y otros Estados del Sur para que aceptaran integrarse en el Imperio. Cuando llegó la redacción de la Constitución de Weimar (1919) fueron sin más suprimidos” " ${ }^{111}$. Innecesario es recordar que la supresión fue promovida por las fuerzas políticas progresistas: liberales y socialistas.

El problema reside en que, en España, todas las fuerzas políticas con representación parlamentaria, tanto en Navarra como en el País Vasco (nacionalistas vascos, regionalistas navarros, PP, PSOE e IU), defienden los derechos históricos con ardor y con pasión (que no con argumentos) de forma asombrosamente unánime. Defensa que, como hemos visto en Cataluña o en Valencia, ha trascendido ya las fronteras de esas Comunidades. Esa sorprendente unanimidad política es la que explica, en cierta medida, que en sede doctrinal hayan sido escasas las voces que se hayan levantado contra los derechos históricos. Pero la honestidad intelectual debe prevalecer sobre la corrección política.

\section{CONCLUSIONES.}

La categoría de los derechos históricos incluye un principio de legitimidad incompatible con el orden material de valores del constitucionalismo democrático y social. E incompatible también con cualquier concepción federal (igualitaria) del Estado. El hecho de que hayan sido recogidos por nuestro último Constituyente no puede hacernos olvidar su esencia antidemocrática y antiigualitaria y sus perturbadores efectos sobre los valores constitucionales de igualdad y solidaridad.

A modo de recapitulación cabe formular las siguientes tesis conclusivas.

Primera. Los derechos históricos son una categoría cuya misma existencia exige la subordinación de la voluntad del pueblo a la historia, y de esta forma contradicen el carácter democrático del Estado. En una Constitución democrática no puede existir una doble legitimidad o una legitimidad alternativa al principio democrático. En la medida en que el contenido de la DAP de la Constitución, excepcionando el principio de legitimidad, es incompatible con la decisión política fundamental del constituyente a favor de la democracia, resulta obligado concluir que dicha disposición es una "norma constitucional inconstitucional". Se trata de una tesis discutible y polémica, pero tan discuti- 
ble como la que afirma que, por definición, ninguna norma constitucional puede ser considerada inconstitucional. ¿Tampoco lo sería la que estableciera que hay ciudadanos de distintas categorías? En última instancia, no hay grandes diferencias entre este último ejemplo y el que nos ocupa.

Segunda. La DAP ha permitido entender que el autogobierno de algunas Comunidades Autónomas españolas (País Vasco y Navarra) tiene un fundamento diferente de la voluntad del Pueblo español, titular del Poder Constituyente. De esta diferencia (inaceptable desde una perspectiva democrática) se han pretendido deducir otras muchas. Desde el derecho de autodeterminación sin éxito alguno, hasta la soberanía fiscal. Este último campo ha resultado el más polémico en la medida en que se ha admitido que en virtud de esos "derechos históricos" el País Vasco y Navarra disfruten de sistemas privilegiados de financiación.

Tercera. El sistema de financiación foral del que disfrutan País Vasco y Navarra no puede ser considerado un derecho, (ni histórico ni de ningún otro tipo) sino un privilegio (constitucionalmente prohibido por el artículo 138.2). Lo que distingue al privilegio del derecho es, precisamente, que se trata de una facultad cuya titularidad se atribuye a unos sujetos y no a otros, sin justificación evidente. Negar que los derechos históricos, en cuanto no son susceptibles de generalización, solo pueden configurarse como privilegios (constitucionalmente prohibidos), es negar lo evidente. En la medida en que el privilegio subsiste gracias al paraguas del derecho histórico, en la praxis estatutaria todos reclaman derechos históricos. La DAP ha provocado asi un lamentable fortalecimiento del historicismo (en detrimento de la democracia) en el desarrollo estatutario.

Cuarta. La pregunta crucial sigue siendo esta: ¿Hasta cuándo se podrá negar a Cataluña lo que se le ha concedido a Navarra y al País Vasco en virtud de su Historia? Y ello porque mientras a unas Comunidades se les niegue lo que a otras se les otorga, resultará imposible cerrar el modelo de Estado en clave federal, esto es, igualitaria. En este sentido, la supresión de la DAP de la Constitución es una exigencia ineludible para hacer de España un Estado Federal. Desde esta perspectiva resulta cada vez más urgente alcanzar un gran pacto de Estado entre las principales fuerzas políticas para acometer una reforma constitucional depurativa de nuestra Constitución. Sólo así podrán remediarse algunos de los graves daños causados a la coherencia y a la funcionalidad del sistema autonómico por el desarrollo estatutario.

Quinta. El problema político reside en que en la España actual, las fuerzas políticas liberales y socialistas no parecen compartir este discurso y muestran un sorprendente entusiasmo por los derechos históricos. En este contexto, como han advertido los profesores Gil Calvo y Sosa Wagner, por la senda de los derechos históricos la deriva autonómica puede conducirnos a medio plazo a la confederalización de España, esto es, a su destrucción como Estado Constitucional unitario. Aunque muchos sonreirán al leer esto y lo considerarán una afirmación exagerada, ese final está en el horizonte. La propia lógica de la cláusula generará una espiral de reivindicaciones que en la medi- 
da en que conduzca a la extensión progresiva del modelo foral al resto de las Comunidades, provocará la sustitución del Estado Constitucional vigente por una Confederación de Estados. Y es que cada vez resultará más difícil a las Cortes Generales negar a Cataluña las facultades (y ello con independencia de que las consideremos derechos o privilegios) que se le han concedido al País Vasco o Navarra. Por de pronto, uno de los principales elementos del modelo foral (confederal), el pactismo o principio de bilateralidad en las relaciones con el poder central (en detrimento del principio de multilateralidad) ha sido asumido ya en casi todos los Estatutos.

Sexta. El Estado Autonómico actual está basado en una glorificación de las diferencias y en una exaltación del particularismo fundado en una errónea comprensión del pluralismo territorial como un valor. Sólo ello explica que, a pesar de haber quedado demostrada su incompatibilidad con los principios y valores de igualdad, justicia y solidaridad, los derechos históricos lejos de ser impugnados hayan experimentado un impresionante desarrollo. Defender los derechos históricos es considerado política e intelectualmente progresista mientras que combatirlos es expresión de una ideología jacobina inaplicable para los tiempos modernos. En este escenario tan confuso como peligroso, la doctrina tiene que hacer pedagogía. Pedagogía racional, liberal y democrática frente a la antipedagogía bistoricista, comunitarista, identitaria y esencialista de los estatuyentes. Corresponde a la doctrina recordar que los derechos son individuales, que sus titulares son las personas y que, en democracia, la voluntad de los ciudadanos no puede quedar, en modo alguno, subordinada a la Historia. Que no cabe apelar a la historia para justificar diferencias que pugnen con la igual libertad de los ciudadanos. Y por otro lado, corresponde a los historiadores investigar, analizar e interpretar, y difundir y explicar la historia real, frente a la historia ficticia construida por las élites políticas autonómicas y reflejadas en los mitos estatutarios.

Séptima. En su sugerente ponencia presentada al CEPC y al Consejo de Estado sobre la reforma constitucional de la sucesión a la Corona, Fernando Rey dijo que declarar inconstitucional una norma constitucional es una suerte de golpe de Estado. Ahora bien, fue Carl Schmitt quien nos recordó que mantener en un mismo texto constitucional principios de legitimidad contradictorios es constitucionalizar la guerra civil. El golpe de estado al que se refiere el profesor Rey no es otro que el acto que pone fin a la guerra civil de la que habla Schmitt. Ocurre sin embargo que, si dicho final implica la victoria del principio democrático, desde la perspectiva de la democracia, el golpe de estado será legítimo. Y es que, efectivamente, - como con mejor o peor fortuna he tratado de exponer en las páginas precedentes- nuestro modelo de organización territorial se desarrolla en un estado de guerra civil (no violenta) entre dos principios en pugna: el principio de legitimidad democrática y el principio de legitimidad bistórica. 
ABSTRACT.- In this work the author seeks to show, on one hand that the dangers and the derived risks of including in the Constitution the statutory privileges through the category of those 'bistorical rights', they were already noticed during the constituent process; for other that the experience has demonstrated that those dangers are real. 